\title{
COMPELLED COMMERCIAL SPEECH
}

\author{
Robert Post*
}

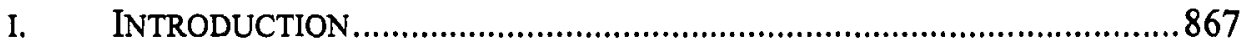

II. THE PLURAL VALUES OF FIRST AMENDMENT DOCTRINE .....................869

A. The Constitutional Value of Commercial Speech ...........................871

B. The Constitutional Value of Public Discourse................................873

C. Distinctions Between Constitutional Protections for

Commercial Speech and for Public Discourse ...............................8 874

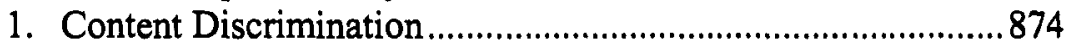

2. Compelled Disclosure of Information.......................................8 876

D. The Importance of Maintaining Constitutional Distinctions

Between Commercial Speech and Public Discourse ......................879

III. THE TENSION BETWEEN ZAUDERER AND CENTRAL HUDSON .................881

A. Zauderer and Intermediate Scrutiny ............................................. 882

B. American Meat Institute v. United States Department of

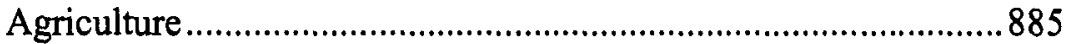

C. The Substantial Government Interest Test ...................................... 889

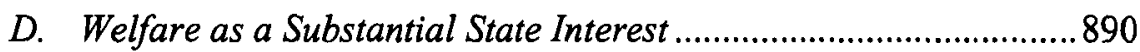

E. Why Is There a Substantial Interest Test? ......................................89

IV. ANCILLARY RESTRICTIONS ON COMPELLED COMMERCIAL SPEECH....900

A. Compelled Disclosures of Fact as Distinct from Opinion ..............901

B. Compelled Graphic Disclosures ...................................................907

C. Compelled Disclosures of "Controversial Information".................910

v. CONCLUSION ................................................................................

\section{INTRODUCTION}

It is a pleasure to deliver the fourth annual $\mathrm{C}$. Edwin Baker Lecture for Liberty, Equality, and Democracy at the West Virginia University College of Law. I counted Ed Baker as a good friend and a precious colleague. I sought out his views and treasured his advice. His work on the First Amendment, and

* Thank you to Conor Clarke for his remarkable and generous research assistance. I am grateful to Al Klevorick, Zorka Milin, Kerry Monroe, Alan Schwartz, Amanda Shanor, Hunter Smith, and James Weinstein for careful and helpful advice, as well as to the collective and deep insights of the Yale Faculty Workshop. 
most especially on the media, is of the first rank. Its prescience, range, and integrity exemplify the very best in American legal scholarship. I mourn Ed Baker's untimely demise, and I miss his companionship.

Ed was most famous for his claim that First Amendment rights protect those "fundamental aspects of individual liberty and choice" that involve using "speech to order and create the world in a desired way and as a tool for understanding and communicating about that world in ways" individuals may find "important." This view led Ed to conclude that the First Amendment should not extend any protection to what is now labeled "commercial speech"-which consists roughly of those communications that accompany the buying and selling of goods in a marketplace.

Ed argued that "commercial speech reflects market forces that require enterprises to be profit oriented," and that these market forces prevent commercial speech from being "a manifestation of individual freedom or choice." Ed would have been deeply distressed by the increasing number of recent Supreme Court decisions using commercial speech doctrine to invalidate perfectly ordinary regulations of the marketplace. ${ }^{3}$ Ed believed that a "postLochner world" was one in which "constitutionally protected liberty does not normally encompass a right to be free of constraints in market transactions." Yet in the context of commercial speech the Court has recently and provocatively proclaimed that although "[t]he Constitution "does not enact $\mathrm{Mr}$. Herbert Spencer's Social Statics[,]" it nevertheless "does enact the First Amendment." 5

Ed would have been especially dismayed at the growing number of circuit court decisions that have used the specific doctrine of "compelled commercial speech" to strike down mandatory commercial disclosures. ${ }^{6}$ Ordinary First Amendment jurisprudence incorporates the principle that " $[t]$ he

1 C. Edwin Baker, Human Liberty and Freedom of SPEech 196 (1989).

$2 \quad$ Id.

3 See, e.g., Sorrell v. IMS Health Inc., 131 S. Ct. 2653 (2011); Thompson v. W. States Med. Ctr., 535 U.S. 357 (2002); United States v. United Foods, Inc., 533 U.S. 405 (2001).

4 C. Edwin Baker, First Amendment Limits on Copyright, 55 VAND. L. REV. 891, 902 (2002).

$5 \quad$ Sorrell, 131 S. Ct. at 2665 (quoting Lochner v. New York, 198 U.S. 45, 75 (1905)). The language comes directly from Justice Thomas's dissent in an earlier commercial speech case, Glickman v. Wileman Bros. \& Elliott, Inc., 521 U.S. 457, 505 n.3 (1997) ("Although the Constitution may not 'enact Mr. Herbert Spencer's Social Statics,' and thus the Government has a considerable range of authority in regulating the Nation's economic structure, part of the Constitution-the First Amendment-does enact a distinctly individualistic notion of 'the freedom of speech,' and Congress may not simply collectivize that aspect of our society, regardless of what it may do elsewhere." (citation omitted)).

6 See, e.g., Nat'l Ass'n of Mfrs. v. SEC, 748 F.3d 359 (D.C. Cir. 2014); Nat'l Ass'n of Mfrs. v. NLRB, 717 F.3d 947 (D.C. Cir. 2013); R.J. Reynolds Tobacco Co. v. FDA, 696 F.3d 1205 (D.C. Cir. 2012); Authentic Beverages Co. v. Tex. Alcoholic Beverage Comm'n, 835 F. Supp. 2d 227 (W.D. Tex. 2011 ). 
right to speak and the right to refrain from speaking are complementary components of the broader concept of 'individual freedom of mind."'" Because Ed believed that constitutional prohibitions against compelled speech were "[t]he poster child of autonomy theory,"8 he would have found especially misplaced First Amendment restraints against compelled commercial speech.

In Ed's memory and honor, I shall use the occasion of this Baker Lecture to explore the burgeoning doctrine of compelled commercial speech. I shall focus on decisions of the District of Columbia Circuit, which has recently issued a spate of significant opinions in this area. We shall encounter a great deal of confusion and misunderstanding, which Ed Baker no doubt would have yearned to clarify.

\section{The Plural Values of First Amendment Doctrine}

I begin my discussion with a recent decision of a panel of the D.C. Circuit, decided on April 14, 2014. The case was National Ass'n of Manufacturers v. SEC ("NAM"), and it partially invalidated a rule promulgated by the SEC pursuant to its obligations under the Dodd-Frank Wall Street Reform and Consumer Protection Act ${ }^{10}$ "to issue regulations requiring firms using 'conflict minerals' to investigate and disclose the origin of those minerals." "Conflict minerals" include gold, tantalum, tin, and tungsten. ${ }^{12}$ These minerals are presently mined in central Africa, and their sale helps to finance and perpetuate a horrendous civil war in the Democratic Republic of the Congo ("DRC"). The Act defines a product to be "'DRC conflict free' if the product does not contain conflict minerals that directly or indirectly finance or benefit armed groups in the Democratic Republic of the Congo or an adjoining country." 13

The SEC rule requires securities issuers who file reports with the SEC under sections 13(a) or 15(d) of the Exchange Act, and who use conflict minerals in a way that is necessary to the production or functionality of their products, to determine the origin of these minerals. ${ }^{14}$ If the issuer "either knows that its necessary conflict minerals originated in covered countries or "has reason to believe' that those minerals 'may have originated' in covered

Wooley v. Maynard, 430 U.S. 705, 714 (1977).

C. Edwin Baker, Autonomy and Free Speech, 27 CONST. COMMENT. 251, 270 (2011).

Nat'l Ass'n of Mfrs. v. SEC, 748 F.3d 359 (D.C. Cir. 2014).

10 Pub. L. No. 111-203 § 1502, 124 Stat. 1376, 2213 (codified at 15 U.S.C. $\$ 78 \mathrm{~m}(2013)$ ).

$11 \quad$ Nat'l Ass' $n$ of Mfrs. v. SEC, 748 F.3d at 363.

$12 \quad I d$. at 362.

$13 \quad 15$ U.S.C. $\$ 78 \mathrm{~m}(\mathrm{p})(1)(\mathrm{D})(2013)$.

14 Nat'l Ass'n of Mfrs. v. SEC, 748 F.3d at 363-64. 
countries," $" 15$ it must file a Conflict Minerals Report as an exhibit to its specialized disclosure report and provide that report on its publicly available Internet website. ${ }^{16}$

Under a separate heading in a specialized report entitled "Conflict Minerals Disclosure," a registrant "must disclose that it has filed a Conflict Minerals Report and provide the link to its Internet website where the Conflict Minerals Report is publicly available." ${ }^{17}$ The requirements of the report are set forth in the regulation, ${ }^{18}$ and they include "[a] description of the measures the registrant has taken to exercise due diligence on the sources and chain of custody of those conflict minerals," a "description of those products" that "have not been found to be 'DRC conflict free," and a description of "the facilities used to process the necessary conflict minerals in those products, if known, the country of origin of the necessary conflict minerals in those products, if known, and the efforts to determine the mine or location of origin with the greatest possible specificity."20

In a split decision, ${ }^{21}$ the D.C. Circuit ruled that the statute and "the Commission's final rule violate the First Amendment to the extent the statute and rule require regulated entities to report to the Commission and to state on their website that any of their products have 'not been found to be DRC conflict free." 22 The judgment is strange because nowhere does the SEC regulation explicitly require firms to label their products as "not found to be 'DRC conflict free." The regulation merely requires issuers to report certain information about products that fail to meet the definition of "DRC conflict free," namely products that contain necessary conflict minerals "that directly or

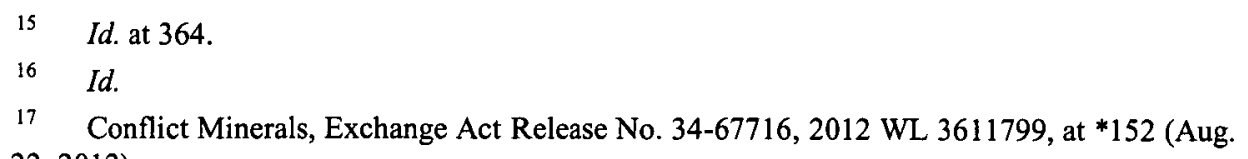
$22,2012)$.

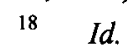

19 Id. at $* 153$.

$20 \quad$ Id. at $* 154$.

21 Judge Randolph authored the majority opinion. He was joined by Judge Sentelle. Judge Srinivasan concurred in part.

22 Nat'l Ass'n of Mfrs. v. SEC, 748 F.3d 359, 373 (D.C. Cir. 2014) (citations omitted) (internal quotation marks omitted). The Court added in a footnote:

The requirement that an issuer use the particular descriptor "not been found to be "DRC conflict free" may arise as a result of the Commission's discretionary choices, and not as a result of the statute itself. We only hold that the statute violates the First Amendment to the extent that it imposes that description requirement. If the description is purely a result of the Commission's rule, then our First Amendment holding leaves the statute itself unaffected.

Id. at 373 n. 14 . 
indirectly finance or benefit armed groups ${ }^{23} \ldots$ in the Democratic Republic of the Congo or an adjoining country. ${ }^{, 24}$ The regulation provides that products that contain necessary conflict minerals obtained "from recycled or scrap sources," 25 or that are otherwise determined "not [to] originate in the Democratic Republic of the Congo or an adjoining country," 26 may be classified as "DRC conflict free."

The court in NAM asserts that the SEC regulation forces commercial entities to speak and thus should be subject to elevated First Amendment scrutiny:

Rational basis review is the exception, not the rule, in First Amendment cases. The Supreme Court has stated that rational basis review applies to certain disclosures of "purely factual and uncontroversial information." But as intervenor Amnesty International forthrightly recognizes, we have held that Zauderer is "limited to cases in which disclosure requirements are 'reasonably related to the State's interest in preventing deception of consumers." No party has suggested that the conflict minerals rule is related to preventing consumer deception. In the district court the Commission admitted that it was not. $^{27}$

The essence of the constitutional controversy surrounding compelled commercial speech is displayed in the logic of this simple paragraph.

\section{A. The Constitutional Value of Commercial Speech}

The first sentence of the paragraph postulates the existence of a "rule" applicable in "First Amendment cases." The court premises its reasoning on the existence of this rule. The court's premise, however, is incorrect. First Amendment jurisprudence contains distinct doctrinal regimes that apply to distinct forms of speech. First Amendment doctrine is plural, not singular. This is because the Constitution values different kinds of speech for different reasons. First Amendment doctrine protects each distinct kind of speech in a

23 The regulation defines an "armed group" as "an armed group that is identified as a perpetrator of serious human rights abuses in annual Country Reports on Human Rights Practices under sections 116(d) and 502B(b) of the Foreign Assistance Act of 1961 relating to the Democratic Republic of the Congo or an adjoining country." Conflict Minerals, Exchange Act Release No. 34-67716, 2012 WL 3611799, at *155 (Aug. 22, 2012) (citations omitted).

24 Id.

$25 \quad I d$.

$26 I d$. at *152 (emphasis in original).

27 Nat'l Ass'n of Mfrs. v. SEC, 748 F.3d at 370-71 (footnote omitted) (citations omitted). 
manner appropriate for safeguarding its particular kind of constitutional value. "Speech as such"28 does not contain any specific constitutional value.

Commercial speech, for example, received no protection at all before $1976 .{ }^{29}$ In the next decade, the Court developed commercial speech doctrine on the explicit premise that "commercial speech [enjoys] a limited measure of protection, commensurate with its subordinate position in the scale of First Amendment values,' and is subject to 'modes of regulation that might be impermissible in the realm of noncommercial expression.",30 From the beginning, therefore, the Supreme Court defined the category of "commercial speech" in a manner designed to exemplify a plural doctrinal regime.

The Court founded this plural regime on "the common-sense distinction between speech proposing a commercial transaction... and other varieties of speech." "31 As it happens, the disclosures at issue in NAM do not concern "speech proposing a commercial transaction"; they do not even concern advertisements. Rather, the case involves reports that purveyors of certain commercial goods must file with the SEC. All parties to NAM nevertheless confidently classify these reports as commercial speech. This suggests that the "common-sense distinction" between commercial speech and "other varieties of speech," which relegates commercial speech to a "subordinate position in the scale of First Amendment values," is not intrinsic to advertising, narrowly understood.

To understand the distinction, one must inquire into the constitutional value embodied in commercial speech. ${ }^{32}$ The Court has made clear since the beginning that commercial speech is to be "constitutionally protected not so much because it pertains to the seller's business as because it furthers the societal interest in the "free flow of commercial information.",33 The authoritative case of Central Hudson Gas \& Electric Corp. v. Public Service Commission $^{34}$ affirms that " $\left.\mathrm{t}\right]$ he First Amendment's concern for commercial speech is based on the informational function of advertising." 35 From the

28 Glickman v. Wileman Bros. \& Elliott, Inc., 521 U.S. 457, 478 (1997) (Souter, J., dissenting).

29 Valentine v. Chrestensen, 316 U.S. 52 (1942), overruled by Va. State Bd. of Pharmacy v. Va. Citizens Consumer Council, Inc., 425 U.S. 748 (1976).

30 Bd. of Trs. v. Fox, 492 U.S. 469, 477 (1989) (alteration in original) (quoting Ohralik v. Ohio State Bar Ass'n., 436 U.S. 447, 456 (1978)).

31 Zauderer v. Office of Disciplinary Counsel, 471 U.S. 626, 637 (1985) (quoting Ohralik, 436 U.S. at $455-56)$.

32 On the difficulty of defining the parameters of commercial speech, see Robert Post, The Constitutional Status of Commercial Speech, 48 UCLA L. REV. 1, 5-25 (2000).

33 First Nat'l Bank v. Bellotti, 435 U.S. 765, 783 (1978) (quoting Va. State Bd. of Pharmacy, 425 U.S. at 764).

$34 \quad 447$ U.S. 557 (1980).

$35 \quad$ Id. at 563 (emphasis added). 
Court's point of view, the constitutional value of commercial speech lies in the information which such speech conveys to an audience.

\section{B. The Constitutional Value of Public Discourse}

The constitutional value in what we may call "paradigmatic" First Amendment speech does not inhere (primarily) in the information that it conveys to an audience. We know this because paradigmatic First Amendment speech is constitutionally protected even if it is deliberately false. "Ordinary" First Amendment doctrine protects the liberty of speakers to communicate or not to communicate in a manner of their own choosing. It is designed to prevent the state from interfering with the message that speakers choose to communicate or the manner in which they choose to communicate it.

Ed Baker theorized that the constitutional value protected by paradigmatic First Amendment doctrine is human autonomy. But because there are many examples of speech important to human autonomy that do not receive constitutional protection, I myself cannot accept Baker's theory. ${ }^{37}$ What I find most salient about paradigmatic First Amendment doctrine is that it protects the speech of persons who participate in "public discourse," who engage in forms of communication constitutionally deemed necessary to form public opinion. ${ }^{38}$ When speakers participate in public discourse, paradigmatic First Amendment doctrine almost always protects their liberty to speak as they choose to speak.

The most convincing explanation of this pattern lies in democratic theory. The First Amendment, as the Court has often affirmed, is "the guardian of our democracy." 39 Democracy is "the rule of public opinion, 'government by public opinion." 40 The First Amendment accordingly guarantees the right of all persons to participate in the formation of "public opinion" because it "is the final source of government in a democratic state." ${ }^{, 41}$ Insofar as public opinion is "the real sovereign in every free" government, ${ }^{42}$ those who seek to shape public opinion should be accorded the unique prerogative of sovereignty-the privilege of self-determination. The liberties guaranteed by "ordinary" First

See United States v. Alvarez, 132 S. Ct. 2537 (2012).

37 Robert C. Post, Democracy, Expertise, ACademic Freedom: A First amendment JURISPRUDENCE FOR THE MODERN STATE 10-15 (2012).

38 See Snyder v. Phelps, 131 S. Ct. 1207, 1220 (2011); Hustler Magazine, Inc. v. Falwell, 485 U.S. 46, 55 (1988).

39 Brown v. Hartlage, 456 U.S. 45, 60 (1982).

40 CARL. SChMitT, Constitutional Theory 275 (Jeffrey Seitzer trans. 2008). "There is no democracy without public opinion." Id.

41 Masses Pub. Co. v. Patten, 244 F. 535, 540 (S.D.N.Y. 1917) (Hand, J.), rev'd, 246 F. 24 (2d Cir. 1917).

42 James Madison, Public Opinion, NAT'L GAZETTE, Dec. 19, 1791, reprinted in 14 THE PAPERS OF JAMES MADISON 170, 170 (Robert A. Rutland et al. eds., 1983). 
Amendment doctrine are designed to help participants in public discourse experience this privilege.

The link between public discourse and democracy lies in the concept of democratic legitimation. If persons seek to influence the content of public opinion, and if they believe that government is potentially responsive to public opinion, First Amendment rights facilitate the expectation that government may potentially be responsive to their views. I call this expectation "democratic legitimation." The First Amendment becomes "the guardian of our democracy" precisely because it safeguards the possibility of democratic legitimation. The First Amendment ensures that each of us may potentially experience the state as responsive to our views.

Persons do not engage in commercial speech in order to influence the content of public opinion, but to facilitate transactions in the marketplace. Constitutional protections for commercial speech therefore do not safeguard the possibility of democratic legitimation. They serve instead to protect the "informational function" of circulating knowledge to those who wish to participate in public discourse. ${ }^{43}$ The constitutional value of this information may be characterized as what I have elsewhere called "democratic competence," which "refers to the cognitive empowerment of persons within public discourse. ${ }^{, 44}$ The thought is that we require knowledge and information in order adequately to govern ourselves.

\section{Distinctions Between Constitutional Protections for Commercial Speech and for Public Discourse}

There are important differences between the constitutional value of democratic legitimacy and the constitutional value of democratic competence. These differences explain the distinction between "paradigmatic" First Amendment doctrine and commercial speech doctrine. Doctrine protecting democratic legitimation safeguards the rights of speakers so that they may come to believe that government is responsive to their views. Doctrine protecting democratic competence, by contrast, safeguards the rights of those who receive information so that they might acquire the knowledge necessary for intelligent self-governance.

\section{Content Discrimination}

This theoretical distinction produces major doctrinal discrepancies. These discrepancies are especially visible in the doctrines of content discrimination and compelled speech. With regard to the former, the state may not engage in content discrimination in public discourse, but it may do so with

\footnotetext{
43 Post, supra note 37 , at $27-43$.

44 Id. at 33-34.
} 
regard to commercial speech. Content discrimination is forbidden in public discourse ${ }^{45}$ because in a democracy all persons have an equal right to influence the content of public opinion, regardless of what they wish to say. Government cannot decide in advance which citizens hold legitimate ideas and which hold illegitimate ideas. It cannot scrub public discourse clean to eliminate deceptive or misleading views. ${ }^{46}$ This is because all citizens have an equal right to speak to influence the direction of democratic policy.

Consider the case of $\mathrm{Dr}$. Oz, the famous physician television host. When Dr. Oz speaks as a citizen in public discourse on his television show, the state cannot sanction him for dispensing deceptive or misleading advice. ${ }^{47}$ As a citizen, $\mathrm{Dr} . \mathrm{Oz}$ is free to exercise his sovereign prerogative to communicate in ways that he believes will make public opinion responsive to his views. He is in this regard equal to every other participant in public discourse. The rule against content discrimination expresses a deep principle of democratic equality.

By contrast, commercial speech is constitutionally valuable because it circulates information necessary for the education of those who participate in public discourse. If the content of commercial speech is inconsistent with this function, the speech fails to serve its constitutional purpose. Thus if Dr. Oz were to use his television show to engage in commercial speech to sell medical supplements, as he in fact came close to doing, his communication would immediately become entangled in a "vast regulatory apparatus in both the federal government and the states ... to control ... potentially misleading or deceptive speech."48

45 Turner Broad. Sys., Inc. v. FCC, 512 U.S. 622, 642 (1994).

46 See, e.g., United States v. Alvarez, 132 S. Ct. 2537 (2012) (striking down a federal statute making it a crime falsely to claim to have received the congressional medal of honor); 281 Care Comm. v. Ameson, 766 F.3d 774 (8th Cir. 2014) (striking down a statute making it a crime to knowingly, or with reckless disregard for the truth, make a false statement about a proposed ballot initiative).

47 See King v. Governor of N.J., 767 F.3d 216, 229-32 (3d Cir. 2014); Pickup v. Brown, 740 F.3d 1208, 1227-28 (9th Cir. 2014); Bailey v. Huggins Diagnostic \& Rehab. Ctr., Inc., 952 P.2d 768, 772 (Colo. App. 1997); Julia Belluz, Meet the Medical Student Who Wants To Bring Down Dr. Oz, Vox, (Oct. 2, 2014, 8:40 AM), http://www.vox.com/2014/7/12/5891451/meet-themedical-student-who-wants-to-bring-down-dr-oz-quackery?utm_medium=social\&utm_source $=$ facebook\&utm_name=share-button\&utm_campaign=vox\&utm_content=article-share-top.

48 Kathleen Sullivan, Cheap Spirits, Cigarettes, and Free Speech: The Implications of 44 Liquormart, 1996 SUP. CT. REV. 123, 153. For Dr. Oz's entanglements with the FTC, see Jen Christensen \& Jacque Wilson, Congressional Hearing Investigates Dr. Oz 'Miracle' Weight Loss Claims, CNN (June 19, 2014, 9:54 AM), http://www.cnn.com/2014/06/17/health/senate-grills-droz/; Dr. Oz's and the Magic Green Coffee Beans: Nothing but a Tall Tale, JAMES RANDI EdUC. FouND. (Oct. 24, 2014), http://web.randi.org/swift/dr-ozs-and-the-magic-green-coffee-beansnothing-but-a-tall-tale; Terrence McCoy, Half of Dr. Oz's Medical Advice Is Baseless or Wrong, WASH. POST, Dec. 19, 2014, http://www.washingtonpost.com/news/morning-mix/wp/2014/12/ 19/half-of-dr-ozs-medical-advice-is-baseless-or-wrong-study-says/. 
We regulate misleading commercial speech because " $[\mathrm{t}]$ he First Amendment's concern for commercial speech is based on the informational function of advertising.... Consequently, there can be no constitutional objection to the suppression of commercial messages that do not accurately inform the public about lawful activity." ${ }^{, 49}$ It is basic doctrine that " $[\mathrm{t}]$ he First Amendment ... does not prohibit the State from insuring that the stream of commercial information flow[s] cleanly as well as freely." ${ }^{50}$ Although the state may not suppress public discourse because it is misleading or deceptive, it may censor deceptive or misleading commercial speech. Speech is ordinarily deemed to be "misleading" from the perspective of a reasonable audience. ${ }^{51}$

Content discrimination is accordingly impermissible within public discourse but routinely practiced within commercial speech. The contrast illustrates how the substance of First Amendment rights is determined by the distinct constitutional values attributed to distinct forms of speech. First Amendment rights of commercial speech are formulated to promote the "informational function" of educating an audience, whereas First Amendment rights of public discourse are formulated to promote democratic legitimation. Contrary to the premise of $N A M$, there is no singular regime of First Amendment doctrine. First Amendment doctrine is plural.

\section{Compelled Disclosure of Information}

An analogous point can be made with respect to a second major contrast between the doctrine of public discourse and the doctrine of commercial speech. To force a person to speak is to override her autonomous choice to remain silent. Because compelled speech within public discourse compromises the self-determination of speakers, it is forbidden within public discourse. Compelled public discourse undermines democratic legitimation in the same way, and to the same extent, as do restrictions on public discourse.

"There is certainly some difference between compelled speech and compelled silence, but in the context of protected speech, the difference is without constitutional significance, for the First Amendment guarantees 'freedom of speech,' a term necessarily comprising the decision of both what to say and what not to say." 52 Requiring "speech that a speaker would not otherwise make necessarily alters the content of the speech,"53 contradicting the principle that " $[\mathrm{t}]$ he First Amendment mandates that we presume that speakers,

\footnotetext{
49 Cent. Hudson Gas \& Elec. Corp. v. Pub. Serv. Comm'n, 447 U.S. 557, 563 (1980).

so Edenfield v. Fane, 507 U.S. 761, 768 (1993) (alterations in original) (quoting Va. State Bd. of Pharmacy v. Va. Citizens Consumer Council, Inc., 425 U.S. 748, 771-72 (1976)).

51 Omnicare, Inc. v. Laborers Dist. Council Constr. Indus. Pension Fund, 135 S.Ct. 1318 (2015).

52 Riley v. Nat'l Fed'n of the Blind of N.C., Inc., 487 U.S. 781, 796-97 (1988).

$53 \quad$ Id. at 795 .
} 
not the government, know best both what they want to say and how to say it."54 "The essential thrust of the First Amendment is to prohibit improper restraints on the voluntary public expression of ideas... There is necessarily... a concomitant freedom not to speak publicly, one which serves the same ultimate end as freedom of speech in its affirmative aspect.",55

For purposes of First Amendment doctrine, there is a constitutional symmetry between restrictions on public discourse and compulsions to participate in public discourse. But this symmetry does not exist within the domain of commercial speech. Because the constitutional value of commercial speech lies in the circulation of information, restrictions on commercial speech and compulsions to engage in commercial speech are constitutionally asymmetrical. Regulations that force a speaker to disgorge more information to an audience do not contradict the constitutional purpose of commercial speech doctrine. They may even enhance it. ${ }^{56}$

Zauderer $v$. Office of Disciplinary Counsel, ${ }^{57}$ to which NAM refers, explicitly adopts this reasoning. In Zauderer, the Court upheld a state requirement that attorney advertisements contain particular factual disclosures:

Appellant, however, overlooks material differences between disclosure requirements and outright prohibitions on speech. In requiring attorneys who advertise their willingness to represent clients on a contingent-fee basis to state that the client may have to bear certain expenses even if he loses, Ohio has not attempted to prevent attorneys from conveying information to the public; it has only required them to provide somewhat more information than they might otherwise be inclined to present. We have, to be sure, held that in some instances compulsion to speak may be as violative of the First Amendment as prohibitions on speech. ...

But the interests at stake in this case are not of the same order as those discussed in Wooley, Tornillo, and Barnette. Ohio has not attempted to "prescribe what shall be orthodox in politics, nationalism, religion, or other matters of opinion or force citizens to confess by word or act their faith therein." The State has attempted only to prescribe what shall be orthodox in commercial advertising, and its prescription has taken the form

\footnotetext{
$54 \quad$ Id. at $790-91$.

$55 \quad$ Harper \& Row Publishers, Inc. v. Nation Enters., 471 U.S. 539, 559 (1985) (quoting Estate of Hemingway v. Random House, Inc., 244 N.E.2d 250, 255 (1968)).

56 This analysis often holds for compelled speech outside the context of public discourse, as for example with respect to the compelled speech of lawyers and doctors. See Robert Post, Informed Consent to Abortion: A First Amendment Analysis of Compelled Physician Speech, 2007 U. ILL. L. REV. 939.
}

57

471 U.S. 626 (1985). 
of a requirement that appellant include in his advertising purely factual and uncontroversial information about the terms under which his services will be available. Because the extension of First Amendment protection to commercial speech is justified principally by the value to consumers of the information such speech provides, appellant's constitutionally protected interest in not providing any particular factual information in his advertising is minimal. Thus, in virtually all our commercial speech decisions to date, we have emphasized that because disclosure requirements trench much more narrowly on an advertiser's interests than do flat prohibitions on speech, "warning[s] or disclaimer[s] might be appropriately required ... in order to dissipate the possibility of consumer confusion or deception."

We do not suggest that disclosure requirements do not implicate the advertiser's First Amendment rights at all. We recognize that unjustified or unduly burdensome disclosure requirements might offend the First Amendment by chilling protected commercial speech. But we hold that an advertiser's rights are adequately protected as long as disclosure requirements are reasonably related to the State's interest in preventing deception of consumers. ${ }^{58}$

Zauderer emphasizes the asymmetry between prohibitions on commercial speech and compulsions to engage in commercial speech. ${ }^{59}$ The former inhibits the circulation of information; the latter augments it. "Because the extension of First Amendment protection to commercial speech is justified principally by the value to consumers of the information such speech provides, appellant's constitutionally protected interest in not providing any particular factual information in his advertising is minimal."

Contrary to $N A M$, there is nothing in this reasoning that turns on the nature of the specific government interests requiring compelled commercial disclosures. Zauderer's logic instead rests on the premise that "disclosure requirements trench much more narrowly on an advertiser's interests than do flat prohibitions on speech ...." Although the particular state interest at issue in Zauderer happened to be that of preventing consumer deception, Zauderer's conclusion is propelled by the "minimal" nature of a commercial speaker's

\footnotetext{
58 Id. at 650-51 (citations omitted).
}

$59 \quad$ See Disc. Tobacco City \& Lottery, Inc., v. United States, 674 F.3d 509, 552 (6th Cir. 2012) (In the context of commercial speech, "[1]aws that restrict speech are fundamentally different than laws that require disclosures, and so are the legal standards governing each type of law.").

60 Zauderer, 471 U.S. at 628.

61 Id. at 651 . 
First Amendment interests in not being compelled to disclose "purely factual and uncontroversial information" in the context of commercial speech. ${ }^{62}$

The First Amendment analysis of NAM is thus exactly backwards. Citing two Supreme Court cases addressing public discourse ${ }^{63}$ NAM concludes that " $t h[\mathrm{e}]$ general rule, that the speaker has the right to tailor the speech, applies ... equally to statements of fact the speaker would rather avoid." 64 Although this rule is valid in the context of public discourse, it is inapplicable to regulations of commercial speech. The difference nicely illustrates the plural nature of First Amendment jurisprudence.

\section{The Importance of Maintaining Constitutional Distinctions Between Commercial Speech and Public Discourse}

There is an important reason why the Court created commercial speech according to different principles than "ordinary" First Amendment jurisprudence. The Court took great care to avoid postulating the constitutional autonomy of the commercial speaker. This is because Lochnerism had insisted on safeguarding the autonomy of commercial actors to exercise "constitutional freedom of contract." ${ }^{.65}$ When the constitutional immunities necessary to sustain this freedom proved radically incompatible with the managed economy required by 20 th century circumstances, Lochner was repudiated and consigned to the anti-canon. ${ }^{66}$

Aware of this history, the Court at the end of the 20th century made certain to justify commercial speech doctrine in a manner that would avoid resurrecting an impossible tension between commercial regulation and constitutional immunities. ${ }^{67}$ It deliberately refused to attribute First Amendment autonomy rights to commercial actors.

\footnotetext{
62 Id.

63 Nat'l Ass'n of Mfrs. v. SEC, 748 F.3d 359, 371 (D.C. Cir. 2014) (quoting Hurley v. Irish-
} Am. Gay, Lesbian \& Bisexual Grp., 515 U.S. 557, 573-74 (1995)) (citing Riley v. Nat'l Fed. of the Blind of N.C., Inc., 487 U.S. 781,797 (1988)).

64 Id. (alterations in original) (quoting Hurley, 515 U.S. at 573-74).

65 Coppage v. Kansas, 236 U.S. 1, 13 (1915).

66 Jamal Greene, The Anticanon, 125 HARV. L. REV. 379 (2011).

67 See, e.g., Cent. Hudson Gas \& Elec. Corp. v. Pub. Serv. Comm'n of N.Y., 447 U.S. 557, 562-63 (1980) ("[O]ur decisions have recognized "the "commonsense" distinction between speech proposing a commercial transaction, which occurs in an area traditionally subject to government regulation, and other varieties of speech."' (quoting Ohralik v. Ohio State Bar Ass'n, 436 U.S. 447, 455-56 (1978))); see also id. at 562-63 (citing Thomas H. Jackson \& John Calvin Jeffries, Jr., Commercial Speech: Economic Due Process and the First Amendment, 65 VA. L. REV. 1, 38-39 (1979)) ("The Constitution therefore accords a lesser protection to commercial speech than to other constitutionally guaranteed expression."). Jackson and Jeffries were among the commentators who most presciently and eloquently adverted to the potential tension between commercial speech doctrine and the autonomous commercial agent protected by Lochner. See 
Virtually all commercial transactions are consummated through contracts, and all contracts exist in the medium of language. If the First Amendment were interpreted to endow commercial speakers with autonomy interests in the words of their contracts, Lochner would be revived. ${ }^{68}$ Every rent control statute could be re-characterized as a restriction on permissible language within commercial contracts. That is why the Court was careful to avoid speaker autonomy rights in its formulation of commercial speech. It instead attributed constitutional value to the information communicated by commercial speech to an audience.

The tension between commercial regulation and the autonomy of commercial speakers is vividly apparent in NAM: the opinion is silent about the massive conflict minerals reports that issuers are required to file. The court chooses instead to focus on the relatively narrow question of whether issuers can be compelled to use the specific phrase "not found to be 'DRC conflictfree." ${ }^{\prime 69}$ Surely if $N A M$ were seriously concerned with protecting the autonomy of a speaking subject, the mandated filing of conflict minerals reports would constitute a far more significant intrusion than the use of the seven words "not found to be 'DRC conflict-free."' One can discern in NAM's eloquent silence the manifest difficulty of any serious judicial effort to resurrect an autonomous speaking subject in the midst of pervasive and routine commercial regulations.

At the root of $N A M$ 's silence is the widely-shared conviction that the purpose of the First Amendment is to create a communicative space for Americans collectively to determine whether, and to what extent, they wish to regulate marketplace actors. There may be particular constitutional provisions, like the Takings Clause, that explicitly limit government regulations of the market. But the First Amendment is not such a provision. The First Amendment instead protects our ability to deliberate whether and how we wish to control our economy.

If the First Amendment were instead interpreted as protecting the autonomy of economic actors, it would mutate from a charter of democratic discussion into a constraint on democratic policymaking. The First Amendment

Cent. Hudson, 447 U.S. at 589 (Rehnquist, J., dissenting) ("The Court's decision today fails to give due deference to this subordinate position of commercial speech. The Court in so doing returns to the bygone era of Lochner v. New York, in which it was common practice for this Court to strike down economic regulations adopted by a State based on the Court's own notions of the most appropriate means for the State to implement its considered policies. I had thought by now it had become well established that a State has broad discretion in imposing economic regulations. As this Court stated in Nebbia v. New York: '[T]here can be no doubt that upon proper occasion and by appropriate measures the state may regulate a business in any of its aspects ...."' (citations omitted)).

68 See, e.g., Nordyke v. Santa Clara Cnty., 110 F.3d 707 (9th Cir. 1997) (holding that state regulations of contract offers and acceptances are commercial speech and must be subject to review under Central Hudson).

69 Nat'l Ass'n of Mfrs. v. SEC, 748 F.3d 359, 375 (D.C. Cir. 2014). 
would then no longer establish a political framework empowering "We the People" to decide which economic philosophy we choose democratically to adopt. It would instead constitutionally impose on the entire country a particular economic philosophy, one with close affinities to the libertarian premises of Herbert Spencer. The striking silence of $N A M$ underscores the frailty of any such constitutional vision.

\section{THE TENSION BETWEEN ZAUDERER AND CENTRAL HUDSON}

The constitutionality of restrictions on commercial speech is assessed according to the four prongs of the canonical Central Hudson test, which provides:

In commercial speech cases, then, a four-part analysis has developed. At the outset, we must determine whether the expression is protected by the First Amendment. For commercial speech to come within that provision, it at least must concern lawful activity and not be misleading. Next, we ask whether the asserted governmental interest is substantial. If both inquiries yield positive answers, we must determine whether the regulation directly advances the governmental interest asserted, and whether it is not more extensive than is necessary to serve that interest. ${ }^{70}$

The Central Hudson test has had a rocky history. At moments it looked as if it were about to be overruled. ${ }^{71}$ But it has now seemingly stabilized, and the four distinct prongs of the Central Hudson test appear to have re-assumed their old authority.

The difficulty with the Central Hudson test is that it offers little guidance about how a court should apply its last three prongs. Exactly which state interests are "substantial"? How "directly" must a state regulation advance a substantial government interest? How narrowly tailored must a regulation be? The Court has offered only inconsistent and vague guidance on these questions. $^{72}$ A consensus seems to have formed that the Central Hudson test should be applied in a manner that exemplifies "intermediate scrutiny."73 The

\footnotetext{
70 Cent. Hudson, 447 U.S. at 566.

71 See Thompson v. W. States Med. Ctr., 535 U.S. 357, 367-68 (2002); 44 Liquormart, Inc. v. Rhode Island, 517 U.S. 484 (1996).

72 Compare, e.g., Posadas de P.R. Assocs. v. Tourism Col., 478 U.S. 328 (1986), with 44 Liquormart, 517 U.S. 484.

73 Fla. Bar v. Went For It, Inc., 515 U.S. 618, 623 (1995); King v. Governor of N.J., 767 F.3d 216, 234 (3d Cir. 2014); Safelite Grp., Inc. v. Jepsen, 764 F.3d 258, 261 (2d Cir. 2014); Educ. Media Co. at Va. Tech, Inc. v. Insley, 731 F.3d 291, 297 (4th Cir. 2013).
} 
capacious phrase is meant to shelter a large divergence of practice in the application of the last three prongs of the Central Hudson test.

\section{A. Zauderer and Intermediate Scrutiny}

What is clear is that the Supreme Court intended the Central Hudson test to contrast sharply with the doctrinal standard advanced in Zauderer. The regulations under review in Zauderer involved both restrictions on attorney advertisements and disclosures that attorneys were compelled to make within their advertisements. In ascertaining the constitutionality of the restrictions, Zauderer applied the Central Hudson test. ${ }^{74}$ But when it came to analyzing the disclosure requirements, Zauderer explicitly rejected the invitation to apply Central Hudson. ${ }^{75}$ It reasoned that there were "material differences between disclosure requirements and outright prohibitions on speech."76 Zauderer concluded:

We do not suggest that disclosure requirements do not implicate the advertiser's First Amendment rights at all. We recognize that unjustified or unduly burdensome disclosure requirements might offend the First Amendment by chilling protected commercial speech. But we hold that an advertiser's rights are adequately protected as long as disclosure requirements are reasonably related to the State's interest in preventing deception of consumers. ${ }^{77}$

Zauderer consciously repudiated the Central Hudson test in the context of compelled commercial speech. The poorly crafted last sentence in the passage just cited has mislead some courts, including $N A M$, into concluding that Zauderer proposed a distinct test only in the context of state-mandated disclosures designed to prevent the "deception of consumers." 78 As I have suggested, this is a flat and tendentious misreading of Zauderer, which should be interpreted as holding that commercial disclosure requirements for "purely factual and uncontroversial information" are constitutional "as long as" they "are reasonably related" to an appropriate state interest. ${ }^{79}$

In using the language of "reasonable relationship," Zauderer selected language deliberately designed to harmonize with the deference that courts

\footnotetext{
74 Zauderer v. Office of Disciplinary Counsel, 471 U.S. 626, 641, 644, 647 (1985).

$75 I d$. at 650 . The attorney in the case had argued that the constitutionality of the mandated disclosures should be decided by "precisely the same inquiry as determining the validity of the restrictions on advertising." Id. at 649.

Id. at 650 .

Id. at 651 .

See, e.g., R.J. Reynolds Tobacco Co. v. FDA, 696 F.3d 1205, 1213-14 (D.C. Cir. 2012).

Zauderer, 471 U.S. at 651.
} 
apply to ordinary commercial regulations. Because commercial speakers retain "minimal" First Amendment interests, Zauderer does not employ the specific vocabulary of "rational basis" review, which would have suggested extreme judicial deference. It instead adopts terminology that unequivocally locates judicial review further toward the deferential end of the spectrum than the intermediate scrutiny authorized by Central Hudson.

In the early days of the administrative state, command and control regulations were common and routine. But as we have learned more about the complexities of the marketplace, as we have acquired greater respect for the autonomy of marketplace actors, there has been a marked shift toward forms of regulation that force the disclosure of information believed necessary for educated participation in the marketplace. ${ }^{80}$ Information-forcing regulations take a wide variety of forms and are established for a wide variety of reasons. Many of these reasons have little to do with protecting consumers from false or misleading information.

A common justification for information-forcing regulations is the reduction of information costs and the consequent enhancement of market efficiency. ${ }^{81}$ Consider, for example, the venerable Truth in Lending Act ("TLA"), which requires the disclosure of loan information

to assure a meaningful disclosure of credit terms so that the consumer will be able to compare more readily the various credit terms available to him and avoid the uninformed use of credit... [and] to assure a meaningful disclosure of the terms of leases ... so as to enable the lessee to compare more readily the various lease terms available to him... [and] enable comparison of lease terms with credit terms where appropriate ... ${ }^{82}$

This purpose is distinct from protecting consumers from deceptive or misleading information.

Information-forcing regulations imposed by the SEC on publicly traded companies provide a compelling and successful example of administrative interventions not primarily designed to protect consumers from deceptive or misleading information. The SEC has "developed an elaborate framework of

80 Howard Beales et al., The Efficient Regulation of Consumer Information, 24 J.L. \& ECoN. 491 (1981).

81 See Alan Schwartz \& Louis L. Wilde, Intervening in Markets on the Basis of Imperfect Information: A Legal and Economic Analysis, 127 U. PA. L. REV. 630, $630 \mathrm{n} .1$ (1979).

8215 U.S.C. $\$ 1601$ (a), (b) (1976); see also SENATE COMM. ON BANKING AND CURRENCY, ThE TRUTH IN LENDING ACT OF 1967, S. REP. No. 90-392 (1st Sess. 1967); House COMM. ON BANKING and CuRrency, Consumer Credit Protection ACt, H.R. Rep. No. 90-1040 (1st Sess. 1967), reprinted in 1968 U.S.C.C.A.N. 1962, 1962-66; NATIONAL COMM'N ON CONSUMER FINANCE, CONSUMER CREDIT IN THE UNITED STATES 171-75 (1972); Schwartz \& Wilde, supra note 81, at 632 n.4. 
disclosure rules that gives public-company shareholders detailed information on the companies in which they invest." ${ }^{83}$ These disclosure requirements ensure "fairer disclosure of information to all investors" and increase "investor confidence in market integrity." decreasing information costs and promoting the efficiency and stability of capital markets. They have helped to make American stock markets the envy of the world.

Economists have produced some evidence that SEC disclosure requirements are successful in increasing the desirability of American capital markets, ${ }^{85}$ but of course these matters are hard to prove and often empirically ascertainable evidence is ambiguous. ${ }^{86}$ It is anybody's guess whether SEC disclosure requirements would survive under the unpredictable and all-toooften harshly applied rules of the Central Hudson test. ${ }^{87}$

Information-forcing disclosures are sometimes mandated to empower consumers to make decisions that align with their long-term interests. A good example is the Nutrition Labeling and Education Act of 1990 ("NLEA"), 88 which authorizes the FDA to impose requirements for food labeling. These labels are not intended to prevent consumer deception, but instead "to help consumers choose more healthful diets through improved access to credible nutrition information." 89 Although there is evidence that these disclosures have been successful in encouraging consumers to select healthier food, ${ }^{90}$ there is no

83 Lucian A. Bebchuk \& Robert J. Jackson, Jr., Shining Light on Corporate Political Spending, 101 GEO. L.J. 923, 928-29 (2013).

84 Selective Disclosure and Insider Trading, Securities Act, No. 7881, 65 Fed. Reg. 51,716, 51,731 (Aug. 24, 2000) (codified at 17 C.F.R. pts. 240, 243, 249 (2013)).

85 Nuno Fernandes et al., Escape from New York: The Market Impact of Loosening Disclosure Requirements, 95 J. FIN. ECON. 129 (2010); Allen Ferrell, Mandated Disclosure and Stock Returns: Evidence from the Over-the-Counter Market, Harvard John M. Olin Discussion Paper No. 453 (2003), available at http://www.law.harvard.edu/programs/corp_gov/papers/ No453.04.Ferrell.pdf.

86 Brian J. Bushee \& Christian Leuz, Economic Consequences of SEC Disclosure Regulation: Evidence from the OTC Bulletin Board, 39 J. ACCT. \& ECON. 233, 234 (2005); Armando Gomes et al., SEC Regulation Fair Disclosure, Information, and the Cost of Capital, 13 J. CORP. FIN. 300 (2007), available at http://www.nber.org/papers/w10567.

87 For an example of a harsh and arbitrary application of the Central Hudson test, see R.J. Reynolds Tobacco Co. v. FDA, 696 F.3d 1205 (D.C. Cir. 2012).

88 Pub. L. No. 101-535, 104 Stat. 2353 (codified as amended in scattered sections of 21 U.S.C.)

89 Jayachandran N. Variyam \& John Cawley, Nutrition Labels and Obesity 1-2 (Nat'1 Bureau of Econ. Research, Working Paper No. 11956, 2006), available at http://www.nber.org/papers/ w11956.pdf.

90 See id.; Alan D. Mathios, The Impact of Mandatory Disclosure Laws on Product Choices: An Analysis of the Salad Dressing Market, 43 J.L. \& ECON. 651 (2000); Marian Neuhouser et al., Use of Food Nutrition Labels Is Associated with Lower Fat Intake, 99 J. AM. DIET Ass'N 45, 49 (1999). 
doubt that they could be constitutionally prohibited by a bull-headed judicial application of the overbreadth prong of Central Hudson. Central Hudson's fourth prong is in fact so vague that it has sometimes functioned chiefly to provide a hunting license for judges who dislike market regulations. ${ }^{91}$

There is thus a great deal at stake in the distinction between the "intermediate scrutiny" of Central Hudson, and the "reasonably related" test of Zauderer. The former jeopardizes the entire movement of American administrative law toward information-forcing strategies. The latter is deliberately designed to avoid the uncertainties that seem endemically associated with the Central Hudson test.

\section{B. American Meat Institute v. United States Department of Agriculture}

It is therefore something of a relief that on July 29,2014 , only about three months after its issuance, NAM $v . S E C$ was overruled by an en banc decision of the D.C. Circuit in a case entitled American Meat Institute $v$. United States Department of Agriculture ("AMI"). ${ }^{92} A M I$ involved regulations of the Department of Agriculture requiring country of origin labels for meat products. The regulations were challenged by trade associations representing livestock

91 See, e.g., Fara Blecker, Beating the Odds: Greater New Orleans Broadcasting Association v. United States Strikes Congressional Ban on Commercial Speech Advertisements of Private Casino Gambling, 20 LOY. L.A. ENT. L. REV. 605, 630-31 (2000) (arguing that "the fourth prong of the Central Hudson test may always lead courts to strike down regulations on commercial speech as unconstitutional because less speech-restrictive ways to achieve the government's asserted interest in regulating speech will surely exist"); Donald W. Garner \& Richard J. Whitney, Protecting Children from Joe Camel and His Friends: A New First Amendment and Federal Preemption Analysis of Tobacco Billboard Regulation, 46 EMORY L.J. 479 (1997) (observing that there is much "judicial second-guessing encouraged by the fourth prong of the Central Hudson test"); Jonathan Weinberg, Note, Constitutional Protection of Commercial Speech, 82 Colum. L. REV, 720,729 (1982) (arguing that the "requirement that commercial speech regulation be no more extensive than necessary . . . can in the discretion of the Court be made impossible to meet," since one can always find a slightly less restrictive alternative). On the essential vagueness of Central Hudson's fourth prong, see Lora E. Barnhart Driscoll, Comment, Citizens United v. Central Hudson: A Rationale for Simplifying and Clarifying the First Amendment's Protections for Nonpolitical Advertisements, 19 GEO. MASON L. REV. 213, 214 (2011) (noting that "courts have not reached a consensus on the proper application of the third and fourth prongs of the Central Hudson test"); Matthew Passalacqua, Note, Something's Brewing Within the Commercial Speech Doctrine, 46 VAL. U. L. REV. 607, 618 (2012) (observing that the fourth prong "has also been subject to multiple interpretations"); Michelle Silva Fernandes, Note, Party Foul: The Fourth Circuit's Improper Application of the Commercial Speech Test in Educational Media Co. at Virginia Tech, Inc. v. Swecker, 80 FORDHAM L. REV. 1325, 1337 (2011) ("While the first two prongs of the Central Hudson test involve a relatively straightforward analysis and have been consistently applied by lower courts, the third and fourth prongs have created a great deal of confusion. Much of this confusion stems from the fact that the Court in Central Hudson did not provide any guidance regarding the burden of proof for each prong or what would constitute sufficient proof to prevail.").

92

760 F.3d 18 (D.C. Cir. 2014). 
producers, feedlot operators and meat packers. They argued that the regulations violated their "First Amendment right to freedom of speech" because it required them "to disclose country-of-origin information to retailers." 93

A panel of the D.C. Circuit had upheld the rule, but the case was reheard en banc to decide "whether the test set forth in Zauderer applies to government interests beyond consumer deception." 94 The court held that "the language with which Zauderer justified its approach . . . sweeps far more broadly than the interest in remedying deception. . . . Zauderer's characterization of the speaker's interest in opposing forced disclosure of . . . information as 'minimal' seems inherently applicable beyond the problem of deception." 95

For the reasons I have discussed, I applaud $A M T$ 's conclusion. But I find it puzzling that in $A M I$ the court took pains to affirm, seemingly by way of dicta, that

to the extent that the pre-conditions to application of Zauderer warrant inferences that the mandate will 'directly advance' the government's interest and show a 'reasonable fit' between means and ends, one could think of Zauderer largely as 'an application of Central Hudson, where several of Central Hudson's elements have already been established. ${ }^{.96}$

\footnotetext{
$93 \quad$ Id. at 21 .

$94 \quad I d$.
}

95 Id. at 22. This conclusion brings the D.C. Circuit into alignment with the Second Circuit, New York State Restaurant Ass'n v. New York City Board of Health, 556 F.3d 114, 133 (2d Cir. 2009); National Electrical Manufacturers Ass'n v. Sorrell, 272 F.3d 104, 113-15 (2d Cir. 2001), and the First Circuit, Pharmaceutical Care Management Ass' $n$ v. Rowe, 429 F.3d 294, 310 (1st Cir. 2005) (Torruella, J.) (noting that it was "obvious that the ... disclosure requirements are 'reasonably related' to Maine's interest in preventing deception of consumers and increasing public access to prescription drugs"); id. at 316 (Boudin, C.J. \& Dyk, J., concurring) (recognizing the state interest as "protecting covered entities from questionable ... business practices" and comparing the Zauderer test to that of "the general rational basis test governing all government regulations under the Due Process Clause"); id. at 297-98 (per curiam) (explaining that the opinion of Chief Judge Boudin and Judge Dyk is controlling on the First Amendment issue).

$A M I$ eliminated the major premise of the panel's decision in NAM. The panel in NAM has accordingly granted rehearing and ordered the filing of supplemental briefs that will address, inter alia:

What is the meaning of "purely factual and uncontroversial information" as used in Zauderer and American Meat Institute?

Is determination of what is "uncontroversial information" a question of fact?

Nat'l Ass'n of Mfrs. v. SEC, No. 13-5252, 2014 BL 323950, at *2 (Nov. 18, 2014), granting reh'g to 748 F.3d 359 (D.C. Cir. 2014). For a discussion of these issues, see infra text accompanying notes $156-89$.

96 Am. Meat Inst., 760 F.3d at 26-27. 
It is surely strange that an en banc court summoned to decide whether Zauderer or Central Hudson should govern commercial disclosures compelled for reasons other than preventing consumer deception should issue an opinion that deliberately conflates Zauderer with Central Hudson. ${ }^{97}$

$A M I$ justifies its approach by analogizing Zauderer to the doctrine of res ipsa loquitur. ${ }^{98}$ AMI suggests that compelled disclosures necessarily directly advance the goal of disseminating information in a narrowly tailored way:

To the extent that the government's interest is in assuring that consumers receive particular information..., the means-end fit is self-evidently satisfied when the government acts only through a reasonably crafted mandate to disclose "purely factual and uncontroversial information" about attributes of the product or service being offered. In other words, this particular method of achieving a government interest will almost always demonstrate a reasonable means-ends relationship, absent a showing that the disclosure is "unduly burdensome" in a way that "chill[s] protected commercial speech." 99

This explanation is curious. It almost seems to affirm that the last two prongs of the Central Hudson test are in the context of compelled disclosures satisfied as a matter of tautology. The mandated disclosure of information narrowly advances "the government's interest... in assuring that consumers receive particular information." 100

But this is a patent misreading of Central Hudson. A state's interest in compelling disclosure is not to circulate information for its own sake, but rather to avoid potential consumer deception, or to promote public health, or to

The court had earlier observed that

[h] aving determined that the interest served by the disclosure mandate is adequate, what remains is to assess the relationship between the government's identified means and its chosen ends. Under Central Hudson, we would determine whether "the regulatory technique [is] in proportion to [the] interest," an inquiry comprised of assessing whether the chosen means "directly advance[s] the state interest involved" and whether it is narrowly tailored to serve that end. Zauderer's method of evaluating fit differs in wording, though perhaps not significantly in substance, at least on these facts.

Id. at 25-26 (second, third, and fourth alterations in original) (citations omitted). This is a very odd observation. Zauderer was explicit that it was proposing a test that differed in method and substance from the inquiries required by Central Hudson. See supra notes 75-77 and accompanying text.

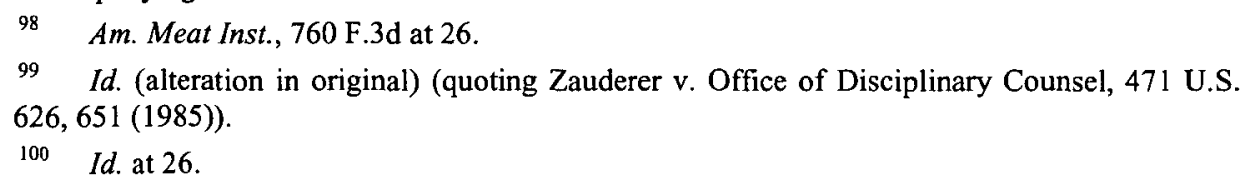


sustain the integrity of capital markets. Whether mandated disclosures directly advance these interests, and do so in a narrowly tailored way, is far from tautological. The Central Hudson test puts the burden of answering these inquiries squarely on the state. ${ }^{101}$ By contrast, Zauderer relieves the state of this burden of justification. ${ }^{102}$ Zauderer explicitly refuses to require the state to answer the specific inquiries that are codified in the last three prongs of the Central Hudson test. It instead poses a more diffuse and generic inquiry: whether the compelled disclosures are "reasonably related" to the state's underlying interest.

I can think of only one reason why $A M I$ might deliberately conflate Zauderer with Central Hudson. Appellant's briefs and arguments in AMI had stressed the question of which state interests might justify government mandated commercial speech. Zauderer does not pose or answer this question. But the second prong of the Central Hudson test does. Central Hudson holds that the state may restrict commercial speech only to advance a "substantial" state interest. $A M I$ seems to entangle itself in the Central Hudson test in order to appropriate the "substantial" state interest test and therefore to retain judicial control over the state interests that might constitutionally justify mandating commercial disclosures. $A M I$ concludes that because compelled disclosure of country of origin labels for meat products is justified by a "substantial" state interest, "we need not decide whether a lesser interest could suffice under Zauderer."

Confusing Zauderer with Central Hudson seems an expensive way to maintain judicial control over the state interests that might justify compelled commercial speech. AMI needn't have swallowed the entire Central Hudson test merely to appropriate prong two. But apparently the court did not feel sufficiently secure to affirm the "substantial" state interest test on its own authority. It is to be hoped that the court's needless and careless references to other dimensions of the Central Hudson test will not further muddy an already confused situation. ${ }^{104}$

\footnotetext{
101 Lorillard Tobacco Co. v. Reilly, 533 U.S. 525, 566-67 (2001).

102 See, e.g., Milavetz, Gallop \& Milavetz, P.A. v. United States, 559 U.S. 229, 249 (2010) (referring to "the less exacting scrutiny described in Zauderer").

103 Am. Meat Inst., 760 F.3d at 23.

104 The signs are not good. See United States v. Wenger, 427 F.3d 840, 849 (10th Cir. 2005). Compare Am. Meat Inst., 760 F.3d at 33 (Kavanaugh, J., concurring) ("Zauderer is best read simply as an application of Central Hudson, not a different test altogether. In other words, Zauderer tells us what Central Hudson's 'tailored in a reasonable manner' standard means in the context of compelled commercial disclosures: The disclosure must be purely factual, uncontroversial, not unduly burdensome, and reasonably related to the Government's interest.... [T] o the extent that some courts, advocates, and commentators have portrayed a choice between the 'tough Central Hudson standard' and the 'lenient Zauderer standard,' I see that as a false choice. As I read it, Zauderer applied and elaborated on Central Hudson's 'tailored in a reasonable manner' requirement and established a demanding set of requirements that the
} 


\section{The Substantial Government Interest Test}

To be fair, the court in $A M I$ was facing a troubling claim. Plaintiffs in the case had argued that country of origin labels for meat products serve no discernible state interest. They claimed that the labels were necessary neither for public health nor for the prevention of consumer deception. Plaintiffs argued that the labels served merely to satisfy "consumers' idle curiosity."105

$A M I$ seems to agree that the state may not compel commercial speech to satisfy the "idle curiosity" of consumers. ${ }^{106}$ Yet $A M I$ is itself unable to construct a concise, convincing justification for why the Department of Agriculture might require meat products to display the country of their origin. ${ }^{107} A M I$ instead blusters, cobbling together a string of disparate factors:

$[\mathrm{H}]$ ere we think several aspects of the government's interest in country-of-origin labeling for food combine to make the interest substantial: the context and long history of country-oforigin disclosures to enable consumers to choose Americanmade products; the demonstrated consumer interest in

Government must meet to justify a compelled commercial disclosure. The majority opinion properly does not equate Zauderer to mere rational basis review and properly insists that the mandatory disclosure here must meet all of the various Zauderer requirements."), and id. at 44 (Brown, J., dissenting) (interpreting the court opinion to agree that Zauderer "is essentially an application of Central Hudson's intermediate scrutiny"), with id. at 28 (Rogers, J., concurring) ("Viewing Zauderer as simply an application of Central Hudson to special circumstances, ... finds support in neither Supreme Court precedent nor the precedent of this court or our sister circuits. Although the en banc court stops short of endorsing this reformulation, stating only that 'one could think of Zauderer largely as an application of Central Hudson,' blurring the lines between the standards portends unnecessary confusion absent further instruction from the Supreme Court. The reformulation of the standards... appears to contravene the Supreme Court's rationale in Zauderer and the purposes served by First Amendment protection of commercial speech." (citations omitted)).

105 Am. Meat Inst., 760 F.3d. at 23 (internal quotation marks omitted).

106 Id.

107 Judge Kavanaugh writes in his concurring opinion:

[T]he Government cannot advance a traditional anti-deception, health, or safety interest in this case because a country-of-origin disclosure requirement obviously does not serve those interests. Rather, the Government broadly contends that it has a substantial interest in 'providing consumers with information.' For Central Hudson purposes, however, it is plainly not enough for the Government to say simply that it has a substantial interest in giving consumers information. After all, that would be true of any and all disclosure requirements. That circular formulation would drain the Central Hudson test of any meaning in the context of compelled commercial disclosures.

Id. at 31 (citation omitted). It is noteworthy that in this passage Judge Kavanaugh cites Central Hudson rather than Zauderer, demonstrating the asymmetry between the tests advanced by the two opinions. The opinion for the Court in $A M I$ engages in precisely the circular reasoning feared by Judge Kavanaugh in intimating an equivalence between Central Hudson and Zauderer. See supra text accompanying note 99 . 
extending country-of-origin labeling to food products; and the individual health concerns and market impacts that can arise in the event of a food-borne illness outbreak. ${ }^{108}$

This is an odd, dispirited list. Either informing a population about the origin of products so that it can take steps to protect itself in the event of health concerns is a substantial state interest or it is not. It is half-hearted to include this rationale in a disjointed list that somehow adds up to a substantial state interest.

The first factor mentioned by the court, the "long history of country-oforigin" disclosures, seems to be merely an indirect way of referencing the wellaccepted tradition of American governments "supporting American manufacturers, farmers, and ranchers as they compete with foreign manufacturers, farmers, and ranchers." 109 The court, like the executive branch, was apparently reluctant explicitly to embrace this interest. Judge Kavanaugh was by contrast willing to name names in his concurring opinion, noting that throughout the litigation of the case "the Executive Branch has refrained... from expressly articulating its clear interest in supporting American farmers and ranchers in order to justify this law, apparently because of the international repercussions that might ensue." 110

\section{Welfare as a Substantial State Interest}

Of the three factors listed by $A M I$, the second factor poses the most important theoretical puzzle. The state's interest in meeting "demonstrated consumer interest in extending country-of-origin labeling to food products" sounds very close to satisfying the curiosity of consumers. ${ }^{11} A M I$ explains this interest "as enabling consumers to make informed choices based on characteristics of the products they wished to purchase, including United States supervision of the entire production process for health and hygiene." 112 It points to surveys "indicating that 71-73 percent of consumers would be willing to pay for country-of-origin information about their food." 113

The question is how the legitimate curiosity of consumers can be distinguished from their "idle" curiosity. "Idle consumer curiosity" sounds

\footnotetext{
108 Am. Meat Inst., 760 F.3d at 23.

109 Id. at 32 (Kavanaugh, J., concurring). The interest in supporting American farmers and ranchers was articulated by Congress when it enacted the statute that directed the Secretary of Agriculture to establish the country-of-origin labelling.

110 Id. The "international repercussions" apparently concern potential WTO proceedings about whether country of origin labels interfere with freedom of trade. See Panel Report, United States-Certain Country of Origin Labelling (COOL) Requirements, WT/DS384/RW (Oct. 20, 2014).

111 Am. Meat Inst., 760 F.3d at 23.

112 Id. at 24.

$113 \quad$ Id.
} 
aimless and pointless, whereas the court seems to refer to evidence that country of origin information might actually reduce information costs in a way that would increase welfare. This suggests that "idle" curiosity does not increase welfare, whereas "legitimate" curiosity does.

Increasing welfare is ordinarily regarded as a substantial state interest. Promoting welfare is a common aim in many areas of commercial law. ${ }^{114}$ Within the utilitarian framework that governs much government administration, the promotion of welfare may even be regarded as one of the great aims of governance. $^{115}$ The relationship between welfare and the circulation of information was stressed by the Supreme Court when it invented commercial speech doctrine in 1976 :

So long as we preserve a predominantly free enterprise economy, the allocation of our resources in large measure will be made through numerous private economic decisions. It is a matter of public interest that those decisions, in the aggregate,

\footnotetext{
114 Contemporary antitrust law is explicitly concerned with welfare maximization. See FTC v. Actavis, Inc., 133 S. Ct. 2223, 2238 (2013) (Roberts, C.J., dissenting) ("The point of antitrust law is to encourage competitive markets to promote consumer welfare."); Brooke Grp. Ltd. v. Brown \& Williamson Tobacco Corp., 509 U.S. 209, 221 (1993) (noting "the antitrust laws' traditional concern for consumer welfare and price competition"); Reiter v. Sonotone Corp., 442 U.S. 330, 343, (1979) (observing that "Congress designed the Sherman Act as a "consumer welfare prescription"” (quoting ROBERT BORK, THE ANTITRUST PARADOX 66 (1978))); see also Peter J. Hammer, Antitrust Beyond Competition: Market Failures, Total Welfare, and the Challenge of Intramarket Second-Best Tradeoffs, 98 MiCH. L. REV. 849, 858 n.21 (2000) ("The economist's 'total welfare' and Judge Bork's 'consumer welfare' are functionally equivalent."). Welfare maximization is also the goal in many influential theories of contract law. See, e.g., Alan Schwartz \& Robert E. Scott, Contract Theory and the Limits of Contract Law, 113 YALE L.J. 541,544 (2003) (arguing that "the state should choose the rules that regulate commercial transactions according to the criterion of welfare maximization").

115 Consider President Reagan's Executive Order 12,291, which was the first executive order that required agencies to use cost-benefit analysis. See Robert W. Hahn \& Cass R. Sunstein, $A$ New Executive Order for Improving Federal Regulation? Deeper and Wider Cost-Benefit Analysis, 150 U. PA. L. REV. 1489, 1489 n.l (2002). In no uncertain terms, Executive Order 12,291 emphasizes that welfare maximization should be a goal of regulation: The order requires that "[r]egulatory action shall not be undertaken unless the potential benefits to society for the regulation outweigh the potential costs to society"; that "[r]egulatory objectives shall be chosen to maximize the net benefits to society"; and that "[a]gencies shall set regulatory priorities with the aim of maximizing the aggregate net benefits to society." Exec. Order No. 12,291, 46 Fed. Reg. 13,193 (Feb. 17, 1981) (repealed 1993). Executive orders in subsequent administrations have added nuance to this framework but have not strayed from the same basic approach. See Exec. Order No. 13,563, 76 Fed. Reg. 3821 (Jan. 18, 2011) (ordering agencies to select approaches that "maximize net benefits"); Exec. Order No. 12,866, 58 Fed. Reg. 51,735 (Sept. 30, 1993) (same).
} 
be intelligent and well informed. To this end, the free flow of commercial information is indispensable. ${ }^{116}$

Whether mandated disclosures actually increase welfare depends, roughly, on whether gains to consumers from receiving the required information outweigh costs to producers in acquiring and distributing that information. Because producers ordinarily already have access to pertinent information, and because the cost of labeling products is typically quite low, mandatory labeling requirements to satisfy sustained consumer demand for information are likely to produce real welfare benefits.

In his concurring opinion, Judge Kavanaugh seems to argue against mandating disclosures even in the presence of sustained consumer demand. He contends,

[A]s the Second Circuit has stated, "Were consumer interest alone sufficient, there is no end to the information that states could require manufacturers to disclose about their production methods." Some consumers might want to know whether their U.S.-made product was made by U.S. citizens and not by illegal immigrants. Some consumers might want to know whether a doctor has ever performed an abortion. Some consumers might want to know the political affiliation of a business's owners. These are not far-fetched hypotheticals, particularly at the state or local level. Do such consumer desires suffice to justify compelled commercial disclosures of such information on a product or in an advertisement? I think not, and history and tradition provide no support for that kind of free-wheeling government power to mandate compelled commercial disclosures. ... I agree with the Second Circuit's statement in Amestoy that "consumer curiosity alone is not a strong enough state interest" to sustain a compelled commercial disclosure. ${ }^{117}$

The passage suggests two distinct reasons why a court might worry about allowing the state to mandate disclosures.

First, consumers may wish to acquire information that raises independent constitutional questions. In Anderson $v$. Martin, ${ }^{118}$ for example, the Court struck down a Louisiana law that required ballots to identify the race of

116 Va. State Bd. of Pharmacy v. Va. Citizens Consumer Council, Inc., 425 U.S. 748, 765 (2013).

117 Am. Meat Inst., 760 F.3d at 31-32 (citation omitted).

118375 U.S. 399 (1964). 
candidates. The Court characterized the law as encouraging "voters to discriminate upon the grounds of race." 119

[B]y placing a racial label on a candidate at the most crucial stage in the electoral process - the instant before the vote is cast-the State furnishes a vehicle by which racial prejudice may be so aroused as to operate against one group because of race and for another. This is true because by directing the citizen's attention to the single consideration of race or color, the State indicates that a candidate's race or color is an important-perhaps paramount-consideration in the citizen's choice, which may decisively influence the citizen to cast his ballot along racial lines. ${ }^{120}$

A voter does not violate the Constitution by choosing candidates on the basis of race. But it is constitutionally problematic for the state to use labeling to encourage this behavior. Judge Kavanaugh suggests that compelled commercial speech may at times operate in an analogous way. The state may mandate disclosures that facilitate a taste for constitutionally disfavored discrimination, as would happen, for example, if doctors were compelled to reveal whether they had performed an abortion.

This seems an acute observation. But the argument does not establish that compelling commercial speech to increase welfare is not itself a substantial state interest. It instead establishes that at times the goal of increasing welfare can conflict with other constitutional values, and that courts ought to be cautious about approving compelled commercial speech in the presence of such a conflict.

Second, Judge Kavanaugh implies that setting the bar for compelled disclosures too low might provide governments a free pass "to spread their preferred messages on the backs of others." 21 He quotes the Second Circuit decision in Amestoy to the effect that "[w]ere consumer interest alone sufficient, there is no end to the information that states could require manufacturers to disclose about their production methods."

Amestoy involved a Vermont law requiring retail sellers of milk products to disclose whether a synthetic growth hormone (named rBST) had been used in the production of their products. ${ }^{123}$ There was no evidence indicating that rBST might be harmful to human health. ${ }^{124}$ Nevertheless, it was

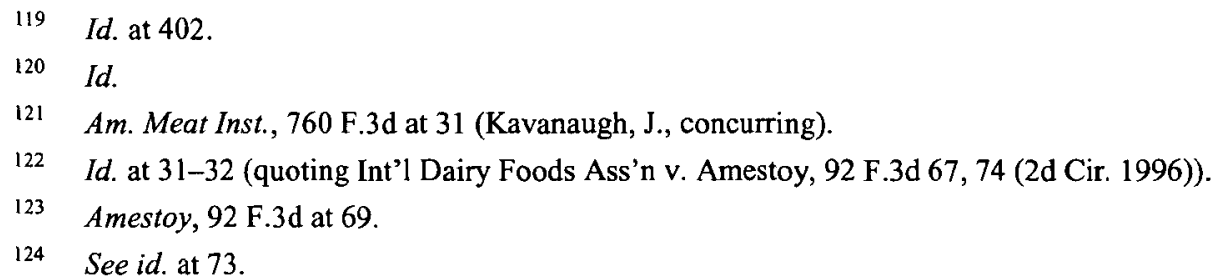


plain that "a majority of Vermonters [did] not want to purchase milk products derived from rBST-treated cows." 125 The Second Circuit found this interest inadequate to justify the required labelling:

Although the Court is sympathetic to the Vermont consumers who wish to know which products may derive from rBST-treated herds, their desire is insufficient to permit the State of Vermont to compel the dairy manufacturers to speak against their will. Were consumer interest alone sufficient, there is no end to the information that states could require manufacturers to disclose about their production methods. For instance, with respect to cattle, consumers might reasonably evince an interest in knowing which grains herds were fed, with which medicines they were treated, or the age at which they were slaughtered. Absent, however, some indication that this information bears on a reasonable concern for human health or safety or some other sufficiently substantial governmental concern, the manufacturers cannot be compelled to disclose it. Instead, those consumers interested in such information should exercise the power of their purses by

Vermont's failure to defend its constitutional intrusion on the ground that it negatively impacts public health is easily understood. After exhaustive studies, the FDA has "concluded that rBST has no appreciable effect on the composition of milk produced by treated cows, and that there are no human safety or health concerns associated with food products derived from cows treated with rBST." Because bovine somatotropin ('BST') appears naturally in cows, and because there are no BST receptors in a cow's mammary glands, only trace amounts of BST can be detected in milk, whether or not the cows received the supplement. Moreover, it is undisputed that neither consumers nor scientists can distinguish rBST-derived milk from milk produced by an untreated cow. Indeed, the already extensive record in this case contains no scientific evidence from which an objective observer could conclude that rBST has any impact at all on dairy products. It is thus plain that Vermont could not justify the statute on the basis of "real" harms.

Id. (citations omitted).

125 Id. at 75 (Leval, J., dissenting). Reasons for this aversion to rBST treated cow-milk included:

(1) They consider the use of a genetically-engineered hormone in the production unnatural; (2) they believe that use of the hormone will result in increased milk production and lower milk prices, thereby hurting small dairy farmers; (3) they believe that the use of rBST is harmful to cows and potentially harmful to humans; and, (4) they feel that there is a lack of knowledge regarding the long-term effects of rBST.

Id. at $75-76$. 
buying products from manufacturers who voluntarily reveal it. $^{126}$

Amestoy and Judge Kavanaugh suggest that if government were authorized to require labels to respond to "mere" consumer interest, government could demand disclosure of information responsive to every whimsical, irrelevant question that might come into a consumer's head. ${ }^{127}$ The cost of such disclosures could endlessly be externalized onto "the backs" of producers. Without some cap on the state's ability to mandate disclosures, the state could impose on producers nearly limitless costs to produce and distribute information.

This objection seems sound, but it is irrelevant to recognizing welfare as a substantial state interest. Compelled disclosures enhance welfare if there is a real demand for the information they contain, a demand robust enough to exceed the costs of ascertaining and distributing the information. Even if such a demand exists, moreover, mandated disclosures might nevertheless impair welfare if they encourage a taste for discrimination ${ }^{128}$ or if they externalize costs by (for example) distributing information that invades privacy. But if mandated disclosures might truly increase welfare, if they might improve market efficiency, this goal ought to count as a substantial state interest.

If the citizens of Vermont distrust FDA conclusions that rBST is safe, and if they are willing to pay more for the identification of milk products made from rBST-treated cows than it costs to produce that identification, why should the Constitution prohibit Vermont from recognizing and responding to that distrust, especially because analogous suspicions of medical omniscience have in the past sometimes proved correct? ${ }^{129}$ Ironically, when 14 years after

126 Id. at 74. Vermont now seems to be going down the same road with a proposed law that requires labeling for food products containing genetically modified products. See VERMONT RIGHT To KNOW GMOS, http://www.vtrighttoknowgmos.org/ (last visited Apr. 2, 2015).

127 This same concern is apparent in the original panel opinion of $N A M$, which set forth its own small parade of horribles, proclaiming in dicta that it would be "obviously repugnant to the First Amendment" for the SEC to require the mandated disclosure of "the labor conditions of ... factories abroad ...." Nat'l Ass'n of Mfrs. v. SEC, 748 F.3d 359, 372 (D.C. Cir. 2014). It is baffling why the panel might have thought it unconstitutional for the SEC to require detailed reports on foreign labor conditions, but constitutional for it to require detailed reports on the use of conflict minerals.

128 There is a respectable argument that mandating the distribution of information to facilitate a taste for discrimination may not promote efficiency. See, e.g., John J. Donohue III, Is Title VII Efficient?, 134 U. PA. L. REV. 1411 (1986); Stewart Schwab, Is Statistical Discrimination Inefficient?, 76 AM. ECON. REV. 228 (1986).

129 Amestoy, 92 F.3d at 76-77 (Leval, J., dissenting) ("[T]here are many possible reasons why a government agency might fail to find real health risks, including inadequate time and budget for testing, insufficient advancement of scientific techniques, insufficiently large sampling populations, pressures from industry, and simple human error. To suggest that a government agency's failure to find a health risk in a short-term study of a new genetic technology should bar 
Amestoy Ohio milk producers sought to label their milk "rBST free," and when the State of Ohio sought by regulation to prevent this labeling on the ground that it was inherently misleading to suggest a difference between milk from rBST-free cows and ordinary milk, the Sixth Circuit struck down the Ohio regulation. ${ }^{130}$ The court noted the increasing "consumer demand for dairy products made with milk from non-rbST-treated cows,"131 and, strikingly, it stressed a record that demonstrated that "compositional difference does exist between milk from untreated cows and conventional milk." "132

The Court invented commercial speech doctrine precisely to protect the circulation of the kind of commercial information that Ohio milk producers wished to distribute. It would seem to follow that the state's interest in distributing similarly welfare-enhancing information ought to be regarded as substantial. The Ohio case illustrates that markets for welfare-enhancing information may develop naturally. ${ }^{133}$ If customers are willing to pay more for hormone free milk, producers have a reason to label their milk rBST free. But there are also well known reasons why such markets may sometimes fail to develop, or may be delayed in their emergence. ${ }^{134}$

Nobel Laureate George Akerlof has theorized some of these reasons. In a classic paper, Akerlof demonstrates that markets in which consumers cannot verify the quality of products may fall apart or fail to materialize. ${ }^{135}$ His insights apply directly to disclosure. Consumers cannot themselves differentiate between milk produced from rBST-treated cows and milk produced from rBST-free cows. A producer may claim that its milk is rBST free, but if consumers cannot independently verify the information provided by the producer, they may not believe its claim. Unable to distinguish between products, consumers may be unwilling to pay the extra price of milk that (producers claim) was produced from rBST-free cows. In such circumstances, producers lack the right incentives to disclose information or even to sell the

a state from requiring simple disclosure of the use of that technology where its citizens are concerned about such health risks would be unreasonable and dangerous. Although the FDA's conclusions may be reassuring, they do not guarantee the safety of rBST.").

130 Int'l Dairy Foods Ass'n v. Boggs, 622 F.3d 628, 637-39 (6th Cir. 2010).

$131 \quad$ Id. at 633.

132 Id. at 636 ("[T]he use of RbST in milk production has been shown to elevate the levels of insulin-like growth factor 1 (IGF-1), a naturally occurring hormone that in high levels is linked to several types of cancers, among other things.").

133 In the economics literature, Paul Milgrom was the first to develop now-classic models of market-driven full voluntary disclosure. For a recent summary, see Paul Milgrom, What the Seller Won't Tell You: Persuasion and Disclosure in Markets, 22 J. ECON. PERSP. 115 (2008).

134 See David Dranove \& Ginger Zhe Jin, Quality Disclosure and Certification: Theory and Practice, 48 J. ECON. LIT. 935, 943 (2010) ("In reality, there are many markets in which voluntary disclosure is incomplete.").

135 See George A. Akerlof, The Market for Lemons: Quality Uncertainty and the Market Mechanism, 84 Q. J. ECON. 488 (1970). 
right products. ${ }^{136}$ And because information has the qualities of a public goodit is non-rivalrous and non-excludable-third-party firms lack incentives to verify the information in the marketplace. ${ }^{137}$

A related problem is that firms may not present consumers with the standardized information necessary to facilitate comparative shopping. If different producers disclose information in different ways, consumers may find it too costly to meaningfully evaluate products. It may require too much work to translate revealed information in a way that would allow the comparison of apples to apples. Often government disclosure regimes are designed precisely to encourage such comparisons by creating standard templates for information disclosure. This is a major design feature of the TLA. Before the TLA, credit companies would provide loan information in ways that made it extremely difficult for consumers to compare prices. ${ }^{138}$

The Second Circuit in Amestoy was thus far too casual in suggesting that consumers interested in information about the hormone content of their milk "should exercise the power of their purses by buying products from manufacturers who voluntarily reveal it." 139 There are many circumstances in

136 See Paul M. Healy \& Krishna G. Palepu, Information Asymmetry, Corporate Disclosure, and the Capital Markets: A Review of the Empirical Disclosure Literature, 31 J. ACCT. \& ECON. 405, 408 (2001) ("[C]onsider a situation where half the business ideas are 'good' and the other half are 'bad.' Both investors and entrepreneurs are rational and value investments conditional on their own information. If investors cannot distinguish between the two types of business ideas, entrepreneurs with 'bad' ideas will try to claim that their ideas are as valuable as the 'good' ideas. Realizing this possibility, investors will value both good and bad ideas at an average level. Therefore, if the lemons problem is not fully resolved, the capital market will rationally undervalue some good ideas and overvalue some bad ideas relative to the information available to entrepreneurs."); see also Michael J. Fishman \& Kathleen M. Hagerty, Mandatory Versus Voluntary Disclosure in Markets with Informed and Uninformed Customers, 19 J. L. ECON. \& ORG. 45, 47 (2003) ("We show that if the fraction of customers who can understand a disclosure is too low, voluntary disclosure may not be forthcoming. ... Our results suggest that we should find mandatory disclosure in markets where product information is relatively difficult to understand.").

137 See John C. Coffee, Jr., Market Failure and the Economic Case for a Mandatory Disclosure System, 70 VA. L. REV. 717, 722 (1984) ("[B]ecause information has many characteristics of a public good, securities research tends to be underprovided. This underprovision means both that information provided by corporate issuers will not be optimally verified and that insufficient efforts will be made to search for material information from nonissuer sources. A mandatory disclosure system can thus be seen as a desirable cost reduction strategy through which society, in effect, subsidizes search costs to secure both a greater quantity of information and a better testing of its accuracy."). Moreover, we might also expect firms to resist disclosure whenever it might lead to more ferocious competition from others in the same market. See Oliver Board, Competition and Disclosure, 57 J. INDUS. ECON. 197 (2009).

138 An explicit purpose of the Act is to ensure the "meaningful disclosure of credit terms so that the consumer will be able to compare more readily the various credit terms available" in the marketplace. 15 U.S.C. $\S 1601$ (a) (2013).

139 Int'l Dairy Foods Ass'n v. Amestoy, 92 F.3d 67, 74 (2d Cir. 1996). 
which government compelled disclosures can increase welfare. If a state asserts welfare as a substantial state interest, Zauderer requires courts to defer to state claims that compelled disclosures serve this interest. To scrutinize whether compelled commercial disclosures actually advance welfare would improperly transform a Zauderer analysis into a Central Hudson review.

Judge Kavanaugh's concurrence nevertheless suggests that judges may be reluctant to accept an asserted substantial state interest in promoting welfare merely upon the government's say so. Perhaps the most appropriate way to navigate this tension is to follow the court's lead in $A M I$, which effectively accepts the government's interest in promoting welfare upon a showing of "demonstrated consumer interest" in the relevant information. ${ }^{140}$ Because the cost of producing and diffusing information is typically quite small, demonstrated consumer interest might be a good proxy for legitimate state interests in enhancing welfare. ${ }^{141}$ If a convincing case can be made that the costs of producing or distributing information are large, then courts may perhaps incrementally add to the state's burden of establishing that it is actually concerned with increasing welfare. The essential point is not whether compelled commercial disclosures actually increase welfare, for any such inquiry would improperly reproduce prong three of the Central Hudson test. The essential point is rather whether a court can be convinced that the purpose of government compelled commercial disclosures is to increase welfare.

\section{E. Why Is There a Substantial Interest Test?}

There is a deep puzzle about why $A M I$ felt so attracted to the second prong of Central Hudson. Why was AMI drawn to the proposition that government can compel commercial speech only to advance a "substantial" interest like health ${ }^{142}$ or safety ${ }^{143}$ or welfare ( $^{144}$ Ordinary state regulations of commercial conduct must surmount no such constitutional barrier. States can regulate commercial behavior for any rational reason. If commercial speakers retain approximately as much constitutional autonomy as do commercial actors, why should we not apply the same analysis to compelled commercial speech?

I can think of two possible reasons for $A M I$ 's retention of the substantial interest test, both of which suggest that the adoption of the test may not be confined to the D.C. Circuit. First, compelled commercial speech cases remain pervasively haunted by the lingering image of the independent speaker, forced by government compulsion to speak in ways that violate autonomy and

\footnotetext{
140 See supra text accompanying note 101.

141 See supra text accompanying note 116.

142 See Rubin v. Coors Brewing Co., 514 U.S. 476, 485 (1995) (noting that government "has a significant interest in protecting the health, safety, and welfare of its citizens").

143 Id.

144 Id.
} 
conscience. This image pervades the court's decision in Amestoy and remains palpable in Judge Kavanaugh's concurring opinion in $A M I I^{145}$ Yet, as Zauderer explicitly holds, speakers retain only "minimal" First Amendment interests in the context of compelled commercial speech. ${ }^{146}$

Although it may be mistaken robustly to protect speaker autonomy in the context of compelled commercial speech, the retention of prong two of Central Hudson may prove a workable compromise to protect "minimal" First Amendment interests whose content and purport remain obscure. It is relatively easy for government plausibly to assert a substantial interest (Central Hudson prong two), as distinct from proving that a regulation actually advances that interest (Central Hudson prong three). The Court has found a wide range of interests to be substantial, ranging from "promoting an educational rather than commercial atmosphere" at a university campus, ${ }^{147}$ to "preventing the commercial exploitation of students and preserving residential tranquility,", 148 to energy conservation, ${ }^{149}$ to "esthetics," 150 to "ensuring the accuracy of commercial information in the marketplace." $"$ "In fact the D.C. Circuit has observed that "the pedestrian nature of those interests affirmed as substantial calls into question whether any governmental interest-except those already found trivial by the Court-could fail to be substantial."152 Retaining prong two may therefore serve as a low-cost placeholder for First Amendment interests not yet fully articulated or understood.

Second, commercial speech doctrine itself connects compelled commercial speech to the formation of public opinion. Commercial speech is protected because it informs those who wish to participate in public discourse. It follows that constitutional doctrine must also regard compelled commercial disclosures as affecting the content of public opinion. Perhaps the D.C. Circuit

145 Id. at 491; see also Am. Meat Inst. v. U.S. Dep't of Agric. 760 F.3d 18, 30-31 (D.C. Cir. 2014) (Kavanaugh, J., concurring) ("As a starting point, all agree that the First Amendment imposes stringent limits on the Government's authority to either restrict or compel speech by private citizens and organizations.... What interests qualify as sufficiently substantial to justify the infringement on the speaker's First Amendment autonomy that results from a compelled commercial disclosure?" (citations omitted)). The image manifestly also grounds Judge Brown's passionate dissent in $A M I$. Judge Brown appeals to a single, unitary "fundamental First Amendment right not to be coerced or compelled to say what one would not say voluntarily," $i d$. at 37 , a right whose purpose is the protection of the autonomous individual, "a free moral agent [who] cannot be coerced without good reason." Id. at 40 .

146 See supra text accompanying note 56.

147 Bd. of Trs. v. Fox, 492 U.S. 469,475 (1989).

148 Id.

149 Cent. Hudson Gas \& Elec. Corp. v. Pub. Serv. Comm'n, 447 U.S. 557, 568 (1980).

150 Cincinnati v. Discovery Network, Inc., 507 U.S. 410, 416 (1993).

151 Edenfield v. Fane, 507 U.S. 761,769 (1993); see also POM Wonderful, LLC v. FTC, 777 F.3d 478, 501 (D.C. Cir. 2015).

152 Kansas v. United States, 16 F.3d 436, 443 (D.C. Cir. 1994). 
wished to retain the second prong of the Central Hudson test to ensure that commercial speech is not compelled to influence public discourse for constitutionally inappropriate reasons. This is a rich and complicated question, and I shall defer its analysis to subsequent parts of this Lecture.

\section{ANCILLARY RESTRICTIONS ON COMPELLED COMMERCIAL SPEECH}

AMI interprets Zauderer's "reasonably related" test to contain three preconditions that deserve distinct articulation. First, a mandated disclosure "must relate to the good or service offered by the regulated party, a link that in Zauderer itself was inherent in the facts, as the disclosure mandate necessarily related to such goods or services." "153 Second, a mandated disclosure must not be

so burdensome that it essentially operates as a restriction on constitutionally protected speech, as in Ibanez $v$. Florida Department of Business and Professional Regulation, where a required disclaimer was so detailed that it "effectively rule[d] out notation of the 'specialist' designation on a business card or letterhead, or in a yellow pages listing." Nor can it sustain mandates that "chill[ ] protected commercial speech."

Third, a mandated disclosure must contain only "purely factual and uncontroversial information' about the good or service being offered."155

The first of these preconditions prohibits the state from arbitrarily selecting commercial speakers as vehicles for the dissemination of information. It holds that if a commercial speaker is compelled to bear the costs of distributing information, the information must be relevant to the market transaction in which the speaker is participating. Commercial regulations normally apply only to persons who choose to engage in the behavior that is regulated. But because speech is abstract and acontextual, any commercial entity might be required to carry any message about any subject at any time. The requirement of materiality is meant to preclude this possibility.

The second precondition follows from the underlying purpose of commercial speech doctrine. The function of the doctrine is to safeguard the circulation of information. If government compels disclosures that interrupt that circulation, either by being so burdensome as to "chill" the communication of information, or by being so detailed as to obscure the uptake of that information, it contradicts the essential goal of commercial speech doctrine. In

\footnotetext{
153 Am. Meat Inst. v. U.S. Dep't of Agric., 760 F.3d 18, 26 (D.C. Cir. 2014).

154 Id. at 27 (alterations in original) (citation omitted) (quoting Ibanez v. Fla. Dep't of Bus. and Prof'1 Regulation, 512 U.S. 136, $146-47$ (1994); Zauderer v. Disciplinary Counsel, 471 U.S. $626,651(1985))$.

155 Id. (quoting Zauderer, 471 U.S. at 651).
} 
such circumstances, compelled disclosures forfeit the relaxed scrutiny of Zauderer and must be analyzed according to the more rigorous standards of Central Hudson, which control judicial review of outright restrictions on commercial speech.

\section{A. Compelled Disclosures of Fact as Distinct from Opinion}

The third precondition has been of central importance in several recent compelled commercial speech decisions of the D.C. Circuit, ${ }^{156}$ and it deserves extended consideration. The third precondition provides that government may require the disclosure only of purely factual and "uncontroversial" information. The most relevant case for interpreting the meaning of this third precondition is United States $v$. United Foods, Inc., ${ }^{157}$ in which the Court makes clear that close constitutional scrutiny will apply to government efforts to compel entities to disseminate ideas or opinions, even within the medium of commercial speech. $^{158}$

Although the precise rationale of United Foods is unclear, we may understand the case to stand for the proposition that audiences do not retain any constitutional interest in obtaining the ideas and opinions of commercial actors, even though they may possess strong constitutional interests in receiving factual information that such actors may possess." The "informational

156 See Nat'l Ass'n of Mfrs. v. NLRB, 717 F.3d 947 (D.C. Cir. 2013); R.J. Reynolds Tobacco Co. v. FDA, 696 F.3d 1205 (D.C. Cir. 2012).

157533 U.S. 405 (2001).

158 At issue in United Foods was a government regulation that the Court interpreted as compelling a commercial entity to communicate the message "that mushrooms are worth consuming whether or not they are branded." 533 U.S. at 411 . This message contains opinion rather than fact, and indeed it contains opinion that contradicts the very message that the plaintiff had wished to convey in its own voice, which was "that its brand of mushrooms is superior to those grown by other producers." Id. United Foods was notoriously ambiguous about the specific test it was employing. $I d$. at 409-10.

159 These latter interests underwrite commercial speech doctrine. I should note that there are many circumstances in which law requires actors to communicate ideas and opinions. Jurors are drafted to give their opinions about the merits of cases. Legal and medical malpractice law are built on the premise that lawyers and doctors are obligated to convey accurate opinions to their clients and patients. On the obligations of doctors, see Mosezhnik v. Berenstein, 33 A.D.3d 895, 898 (N.Y. App. Div. 2006) ("A defendant may be held liable for ordinary negligence upon his or her failure to communicate significant medical findings to a patient or her treating physician."); Bruse v. Brickner, 78 Misc. 2d 999, 1000 (N.Y. Sup. Ct. 1974) ("The patient is damaged by the doctor's negligent failure to communicate and to advise him quite as much as by his doctor's negligent performance of the operation itself."). On the obligations of lawyers, see, e.g., Ryder $v$. Sec 'y, Dep 't of Corr., 521 F. App'x 817, 820 (11th Cir. 2013) (noting inter alia that the lawyer's "cumulative failure to communicate with [the client] over a period of years amounted to more than simple negligence"); People v. Milner, 35 P.3d 670, 676 (Colo. 2001) ("Milner's failure to return the client's phone calls and her failure to communicate with the client constituted a violation of' Colorado rules.); In re Conduct of Groom, 249 P.3d 976, 983 (Or. 2011) (noting 
function" of commercial speech applies to factual information, not to ideas and opinions. ${ }^{160}$ This is especially true with regard to ideas and opinions that a commercial speaker does not actually hold, as was the case in United Foods.

Underlying this conclusion is the close connection between compelled commercial speech and the construction of public opinion. From a constitutional point of view, democratic competence is furthered whenever public opinion is better informed by relevant facts and information. That is why the reluctance of commercial speakers to disclose factual information is irrelevant to the constitutional value of that information. But democratic legitimation may be harmed by the compelled disclosure of opinions that speakers do not actually hold or would choose not to disclose. Public opinion can connect individual to collective self-determination only insofar as it is formed by the clash of opinions that persons are willing to acknowledge as their own. ${ }^{161}$ Government responsiveness to public opinion cannot further democratic legitimation if government action is directed by views that members of the public do not wish to communicate.

This reasoning presupposes a distinction between fact and opinion. This distinction is significant for many areas of First Amendment jurisprudence, most notably defamation. Although the publication of false facts can under certain circumstances be penalized for defamation, the publication of opinion cannot. Experience has demonstrated the difficulty of constitutionally distinguishing fact from opinion. ${ }^{162}$ The challenge is no less daunting in the context of compelled commercial speech, as can be seen in recent decisions of the D.C. Circuit.

NAM's curious focus on the precise phrase "not found to be 'DCR conflict free," for example, might perhaps be explained by the fact that the court viewed the phrase as communicating opinion rather than fact:

that when a client's position is without merit, "the fact that a lawyer's failure to communicate does not prejudice the client does not relieve the lawyer of the ethical duty to communicate"); In re Conduct of Coyner, 149 P.3d 1118, 1120 (Or. 2006) ("The lawyer must communicate bad news as well as good to the client, and failing to do so in a timely manner is neglect of a legal matter."). For a general discussion, see Post, supra note 56, at 950-51.

160 See Entm't Software Ass'n v. Blagojevich, 469 F.3d 641, 652 (7th Cir. 2006).

161 See, e.g., PoST, supra note 37, at 39-41; see also Gilbert v. Minnesota, 254 U.S. 325, 33738 (1920) (Brandeis, J., dissenting). Freedom of speech enhances democracy only if participation in public opinion formation enhances "democratic legitimation." Democratic legitimation occurs when the state is perceived to be responsive to public opinion, which in turn is perceived to be the outcome of genuine debate and discussion. Public opinion loses this representative character when it is instead the outcome of conscripted opinions, or ideas that do not accurately represent the views of speakers.

162 For my own effort to untangle the puzzle, see Robert C. Post, The Constitutional Concept of Public Discourse: Outrageous Opinion, Democratic Deliberation, and Hustler Magazine v. Falwell, 103 HARV. L. REV. 601, 657-61 (1990). 
[I]t is far from clear that the description at issue-whether a product is "conflict free"-is factual and non-ideological. Products and minerals do not fight conflicts. The label "conflict free" is a metaphor that conveys moral responsibility for the Congo war. It requires an issuer to tell consumers that its products are ethically tainted, even if they only indirectly finance armed groups. An issuer, including an issuer who condemns the atrocities of the Congo war in the strongest terms, may disagree with that assessment of its moral responsibility. And it may convey that "message" through "silence." By compelling an issuer to confess blood on its hands, the statute interferes with that exercise of the freedom of speech under the First Amendment. ${ }^{163}$

As defined in applicable SEC regulations, the phrase "not found to be 'DRC conflict free" "refers to a simple factual state of affairs. Either the conflict minerals necessary for a product did or did not originate in the DRC or in an adjoining country. Either payment for the minerals did "directly or indirectly finance or benefit armed groups in the Democratic Republic of the Congo or an adjoining country," or it did not. In Meese v. Keene, ${ }^{164}$ the United States Supreme Court upheld a federal law requiring authors to register their own work as "political propaganda," and to disclose that registration, in part because the statute defined "political propaganda" in an entirely factual manner. ${ }^{165}$

163

Nat'l Ass'n of Mfrs. v. SEC, 748 F.3d 359, 371 (D.C. Cir. 2014). See supra text accompanying note 95 for the questions posed by the NAM panel on rehearing. These questions seem to focus on the fact/opinion distinction.

164481 U.S. 465 (1987).

165 Id. at 477 . The Court reversed the judgment of a district court that had invalidated the application of the statute to a foreign filmmaker. The Court observed that the trial court had made an argument that rested

not on what the statute actually says, requires, or prohibits, but rather upon a potential misunderstanding of its effect. Simply because the term "political propaganda" is used in the text of the statute to define the regulated materials, the court assumed that the public will attach an "unsavory connotation," to the term and thus believe that the materials have been "officially censured by the Government."

Id. at 478-79 (citation omitted). The Court rejected the conclusion of the trial court in part because

Congress' use of the term "political propaganda" does not lead us to suspend the respect we normally owe to the Legislature's power to define the terms that it uses in legislation.... [W] e simply view this particular choice of language, statutorily defined in a neutral and evenhanded manner, as one that no constitutional provision prohibits the Congress from making. Nor do we agree with the District Court's assertion that Congress' use of the term "political propaganda" was "a wholly gratuitous step designed to express the suspicion with which Congress regarded the materials." It is axiomatic that the statutory definition of the term excludes unstated meanings of that term. 
$N A M$, however, may have objected to the impact that the use of the label "not found to be conflict free" might be expected to have on an audience. The panel believed that using the phrase might require a speaker "to confess blood on its hands." In this regard, it is noteworthy that the Fifth Circuit, just two months before the decision in $N A M$, had upheld against First Amendment challenge the registration requirements of the Sex Offender Registration and Notification Act, which require convicted sex offenders to "register, and keep the registration current, in each jurisdiction where the offender resides, where the offender is an employee, and where the offender is a student." 166 Although the mandated registration entails the literal confession of a heinous crime, the Fifth Circuit essentially held that it requires only the disclosure of a fact rather than of a "religious, political, or ideological belief." 167 Regulatory agencies commonly require "wrongdoers" "to make public admissions of past wrongdoing.",168

The decision of the Fifth Circuit strongly suggests that $N A M$ may have confused the substance of a compelled disclosure with the response that a disclosure may likely arouse. No doubt an audience will be inclined to condemn a speaker who reveals a past conviction for a sexual offense, just as it may be inclined to condemn an issuer who admits that it markets products containing conflict minerals not "found to be "DRC conflict-free." This condemnation will surely depend upon opinions about the heinousness of sex offenses or the irresponsibility of using conflict minerals. But the likely arousal of condemnation does not imply that the compelled disclosure is not itself factual.

United Foods effectively prohibits the required circulation of opinions or ideas; it does not preclude mandated factual disclosures that are likely to produce ideas in an audience. As the Sixth Circuit recently observed,

Facts can disconcert, displease, provoke an emotional response, spark controversy, and even overwhelm reason, but that does not magically turn such facts into opinions. As set forth above, whether a disclosure is scrutinized under Zauderer

\footnotetext{
Congress' use of the term "propaganda" in this statute, as indeed in other legislation, has no pejorative connotation. As judges it is our duty to construe legislation as it is written, not as it might be read by a layman, or as it might be understood by someone who has not even read it. If the term "political propaganda" is construed consistently with the neutral definition contained in the text of the statute itself, the constitutional concerns voiced by the District Court completely disappear.
}

Id. at 484-85 (citations omitted).

166 See 42 U.S.C. $\S 16913$ (2013); United States v. Amold, 740 F.3d 1032 (5th Cir. 2014).

167 Arnold, 740 F.3d at 1035.

168 United States v. Philip Morris USA, Inc., 907 F. Supp. 2d 1, 18-19 (D.D.C. 2012) (citing numerous examples of the FTC, the NLRB, and NHTSA requiring convicted defendants to issue "corrective messages"). 
turns on whether the disclosure conveys factual information or an opinion, not on whether the disclosure emotionally affects its audience or incites controversy. ${ }^{169}$

The meaning of a communication must be determined before it can be characterized as either fact or opinion. It is well established in defamation law that meaning must be determined "from the commonsense perspective from which they would be interpreted by the average member of the public."170 Literally read, a statement may seem to consist of a factual assertion, but from a constitutional perspective the meaning of the statement must be determined from the perspective of a reasonable member of the public. The assertion that someone engaged in negotiations with a city had committed "blackmail," for example, cannot constitutionally be interpreted as an accusation of a criminal act so long as a reasonable audience would understand the assertion to signify merely harsh criticism of a bargaining position. ${ }^{171}$ "[E]ven the most careless reader" would recognize the word as "no more than rhetorical hyperbole, a vigorous epithet used" to signify "extremely unreasonable" behavior. ${ }^{172}$ Analogously, $N A M$ 's point might be that although SEC regulations define the phrase "DRC conflict-free" in a factual fashion, a reasonable audience would understand the phrase to mean a confession of ethical taint and culpability. ${ }^{173}$

If this is an accurate account of $N A M$ 's holding, the panel probably should have remanded the case for a factual determination about how the phrase "not found to be 'DRC conflict free"" would be understood by a reasonable reader. ${ }^{174}$ The deeper point, however, is that because the SEC did

169 Disc. Tobacco City \& Lottery, Inc. v. United States, 674 F.3d 509, 569 (6th Cir. 2012), cert. denied, 133 S. Ct. 1996 (2013).

170 Rodney A. Smolla, 1 Law of Defamation $\$ 4: 20$ (2d ed. 2014); see MacLeod v. Tribune Publ'g Co., 343 P.2d 36, 42 (Cal. 1959); Se. Newspapers, Inc. v. Walker, 44 S.E.2d 697, 700 (Ga. Ct. App. 1947); Gough v. Tribune-Journal Co., 275 P.2d 663, 666 (Idaho 1954); Thompson v. Osawatomie Publ'g Co., 156 P.2d 506, 508 (Kan. 1945); Longey v. Slator, 108 A.2d 396, 399 (Vt. 1954); Carwile v. Richmond Newspapers, Inc., 82 S.E.2d 588, 592 (Va. 1954).

171 Greenbelt Coop. Publ'g Ass'n v. Bresler, 398 U.S. 6, 14 (1970).

172 Id.

173 Meese v. Keene, 481 U.S. 465 (1987), seems categorically to reject the determination of meaning by reference to the reasonable reader. But Keene is inconsistent with the way in which most courts in most contexts do and should determine meaning. See Post, supra note 56, at 95260 ; supra notes 160,164. Under Keene's approach, the state could require doctors to inform abortion patients that abortion was "morally wrong," but statutorily define the phrase "morally wrong" to mean "containing scientifically determinable risks."

174 A recent article, using survey technology, has concluded that the readers overwhelmingly find that the phrase "not found to be 'DRC conflict-free" is a statement of fact rather than opinion. Daniel E. Herz-Roiphe, Stubborn Things: An Empirical Approach to Facts, Opinions, and the First Amendment, $113 \mathrm{MICH}$. L. REV. FIRST IMPRESSIONS 47 (2014), available at http://michiganlawreview.org/stubborn-things-an-empirical-approach-to-facts-opinions-and-thefirst-amendment/. 
not prohibit issuers from defining the phrase "not found to be 'DRC conflict free" "in terms of the literal factual criteria of the statute and regulations, it is hard to conclude that the SEC mandated the use of a phrase that would necessarily be understood as an ideological confession rather than as a label signifying certain factual predicates. The SEC left issuers in control of how readers would interpret the meaning of the phrase. If an issuer believed that there was a serious chance that the label would be misunderstood as a confession of taint and culpability, it was free to make sure that its audience would understand the label in its purely factual, legally specified signification. ${ }^{175}$

When legal categories depend upon the meaning of words, the law typically determines meaning in terms of how a reasonable audience would understand the relevant language. The classic illustration is how courts in defamation cases decide the question of defamatory meaning. See, e.g., Hoffman-Pugh v. Ramsey, 312 F.3d 1222, 1225 (11 th Cir. 2002) ("As a general rule, the question of whether a published statement is defamatory is a question for the jury. However, if the statement is not ambiguous and can reasonably have but one interpretation, the question is one of law for the court. After reading and construing the publication as a whole, the court may find that it is not defamatory, that it is defamatory, or that it is ambiguous and the question is one for a jury."); Krohngold v. Nat'l Health Ins. Co., 825 F. Supp. 996, 998 (M.D. Fla. 1993) ("If a publication is subject only to one interpretation, the Court determines whether the statement is defamatory. However, if the publication is ambiguous or subject to divergent interpretation, an issue exists that precludes summary judgment."); Perry v. Cosgrove, 464 So.2d 664, 666 (Fla. Dist. Ct. App. 1985) ("The language of the [potentially defamatory] document should not be interpreted by extremes, but should be construed as the common mind would naturally understand it."). The Court has adopted this approach in other constitutional contexts. Virginia v. Black, 538 U.S. 343 (2003), for example, allows states to prohibit cross burnings that convey the meaning of a "true threat," and the case plainly contemplates that juries will, at least in the first instance, determine the meaning of any particular cross burning. Black has been interpreted as requiring a factfinder to decide how an audience would interpret the meaning of a communication. See also United States v. Schneider, 910 F.2d 1569, 1570 (7th Cir. 1990) ("The test for whether a statement is a threat is an objective one; it is not what the defendant intended but whether the recipient could reasonably have regarded the defendant's statement as a threat."); United States v. Maisonet, 484 F.2d 1356, 1358 (4th Cir. 1973) ("If there is substantial evidence that tends to show beyond a reasonable doubt that an ordinary, reasonable recipient who is familiar with the context of the letter would interpret it as a threat of injury, the court should submit the case to the jury."). The "fighting words" cases are also handled in this way. See, e.g., Tucker v. State, 504 S.E.2d 250, 253 (Ga. Ct. App. 1998) ("The jury is required only to determine that the words uttered would, as a matter of common knowledge, naturally tend to provoke a violent response."); State v. Heiskell, 666 P.2d 207, 211 (Kan. Ct. App. 1983) ("Where words are the gravamen of the offense, however, the jury must find that the words spoken were fighting words, i.e., that they were of such a character that their very utterance caused injury or that they tended to incite the listener to an immediate breach of the peace. Since the jury was not so instructed here, and defendant could thus have been convicted for the use of constitutionally-protected speech, his conviction for disorderly conduct must be reversed."). Consider also how courts handle prosecutions under 18 U.S.C. $\S 876$ (2013), which prohibits threatening communications by mail. See, e.g., United States v. Malik, 16 F.3d 45, 49 (2d Cir. 1994) ("Whether a given writing constitutes a threat is an issue of fact for the trial jury.").

175 In Keene, the Court rested its conclusion in part on the ground that Congress had 


\section{B. Compelled Graphic Disclosures}

The boundary between fact and opinion is an intrinsically troubled area. Difficult cases are bound to arise. The D.C. Circuit recently confronted one such perplexing case in R.J. Reynolds Tobacco Co. v. FDA. ${ }^{176}$ The case involved nine graphic warnings which the FDA required to be affixed to cigarette packages and advertisements. The warnings were challenged under the First Amendment. The court refused to apply Zauderer, in part for the (now repudiated) reason that Zauderer did not apply to disclosures required for reasons other than correcting misleading speech, and in part because the disclosures did "not constitute the type of 'purely factual and uncontroversial' information ... to which the Zauderer standard may be applied."177

FDA concedes that the images are not meant to be interpreted literally, but rather to symbolize the textual warning statements, which provide "additional context for what is shown." But many of the images chosen by FDA could be misinterpreted by consumers.... Moreover, the graphic warnings are not "purely" factual because-as FDA tacitly admits - they are primarily intended to evoke an emotional response, or, at most, shock the viewer into retaining the information in the text warning....

\footnotetext{
simply required the disseminators of such material to make additional disclosures that would better enable the public to evaluate the import of the propaganda. The statute does not prohibit appellee from advising his audience that the films have not been officially censured in any way. Disseminators of propaganda may go beyond the disclosures required by statute and add any further information they think germane to the public's viewing of the materials. By compelling some disclosure of information and permitting more, the Act's approach recognizes that the best remedy for misleading or inaccurate speech contained within materials subject to the Act is fair, truthful, and accurate speech. The prospective viewers of the three films at issue may harbor an unreasoning prejudice against arguments that have been identified as the "political propaganda" of foreign principals and their agents, but the Act allows appellee to combat any such bias simply by explaining-before, during, or after the film, or in a wholly separate context - that Canada's interest in the consequences of nuclear war and acid rain does not necessarily undermine the integrity or the persuasiveness of its advocacy.
}

481 U.S. at 480-81. Cf. Spirit Airlines, Inc. v. U.S. Dept. of Transp., 687 F.3d 403, 414 (D.C. Cir. 2012); Conn. Bar Ass'n v. United States, 620 F.3d 81, 98 (2d Cir. 2010) (noting that nothing in the law precludes a speaker "from providing an assisted person with more information than is contained in the mandated disclosures to ensure accurately informed choices").

176696 F.3d 1205 (D.C. Cir. 2012).

177 Id. at 1216. 
In fact, many of the images do not convey any warning information at all, much less make an "accurate statement" about cigarettes. For example, the images of a woman crying, a small child, and the man wearing a T-shirt emblazoned with the words "I QUIT" do not offer any information about the health effects of smoking. ... These inflammatory images... cannot rationally be viewed as pure attempts to convey information to consumers. They are unabashed attempts to evoke emotion (and perhaps embarrassment) and browbeat consumers into quitting. While none of these images are patently false, they certainly do not impart purely factual, accurate, or uncontroversial information to consumers. Consequently, the images fall outside the ambit of Zauderer. ${ }^{178}$

The proper interpretation of FDA's graphic warnings poses a true puzzle. Zauderer should not be inapplicable merely because compelled disclosures are in graphic rather than textual form. The logic of Zauderer is pertinent so long as compelled disclosures communicate information. It should not matter whether information is conveyed through the medium of text or of images. The picture of the skull and crossbones designates poison; ${ }^{179}$ the universal symbol for radioactivity designates the presence of radioactive danger. These images are concise and effective ways of conveying important factual information.

Zauderer should be applicable even if compelled disclosures produce reactions of alarm or strong emotion. Textual disclosures can produce these emotions just as easily as can graphic disclosures, as anyone who reads mandated FDA warnings about the side effects of drugs knows perfectly well. The Court correctly observed in Cohen v. California" ${ }^{180}$ that the "emotive" impact of language is often intrinsically connected to its "cognitive force."181 The two cannot be artificially separated. ${ }^{182}$

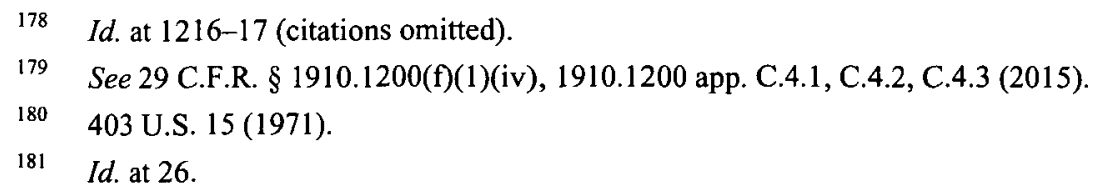

182 See Caroline Mala Corbin, Compelled Disclosures, 65 AlA. L. REV. 1277, $1306-07$ (2014). In $A M I$, the court came close to wrestling with this topic. The American Meat Institute had objected to being compelled to use the word "slaughter" because of it's unsavory emotional implications. The court responded:

As to whether it is "controversial," AMI objected to the word "slaughter" in its reply brief. Though it seems a plain, blunt word for a plain, blunt action, we can understand a claim that "slaughter," used on a product of any origin, might convey a certain innuendo. But we need not address such a claim because the 2013 rule allows retailers to use the term "harvested" instead, and AMI has posed no objection to that. And AMI does not disagree with the 
The required FDA graphic warnings are constitutionally ambiguous, however, because graphic images can sometimes convey opinion instead of information. The scarlet letter affixed to Hester Prynne communicated not merely the fact of adultery, but also ideas of disgrace, shame, and guilt. The Nazis used the symbol of the Jewish Star to communicate far more than the mere fact of Jewishness. They deployed the symbol to convey judgments of disgust, avoidance, and condemnation. Mandated disclosures like these should not come within the purview of the Zauderer test. ${ }^{183}$ If a reasonable reader would interpret the graphic images selected for cigarette packages by the FDA to convey the message "that consumers should reject this otherwise legal, but disfavored product,"184 the required disclosures would come under the holding of United Foods instead of Zauderer, because the mandated images would communicate opinion rather than factual information. ${ }^{185}$

The difficulty is that graphic images are notoriously hard to interpret. ${ }^{186}$ Some graphic images probably function to communicate both information and opinion. In such cases, courts have no option but to muddle through, using the usual tools at their disposal for determining how a reasonable reader would best interpret the meaning of required graphic communications. ${ }^{187}$

truth of the facts required to be disclosed, so there is no claim that they are controversial in that sense.

Am. Meat Inst. v. U.S. Dep't of Agric., 760 F.3d 18, 27 (D.C. Cir. 2014).

183 Imagine, for example, if a state were to require abortion clinics to post graphic images of dismembered fetuses on their advertisements and signage.

184 R.J. Reynolds Tobacco Co. v. FDA, 696 F.3d 1205, 1212 (D.C. Cir. 2012).

185 It is noteworthy that Herz-Roiphe, supra note 174, at 57, concludes that the vast majority of persons understand the graphic warnings on cigarette packs to communicate factual information.

186 Recent decisions dealing with compelled ultrasounds for patients seeking abortions raise important questions about the boundary between fact and opinion in the context of graphic presentations. Compare, e.g., Stuart v. Camnitz, 774 F.3d 238, 246 (4th Cir. 2014), with Tex. Med. Providers Performing Abortion Servs. v. Lakey, 667 F.3d 570, 577-78 (5th Cir. 2012).

187 For an informative discussion, see Disc. Tobacco City \& Lottery, Inc., v. United States, 674 F.3d 509, 559-61 (6th Cir. 2012). Zauderer itself rejected any categorical rule banning illustrations in commercial speech on the ground that graphic images were inherently "deceptive or manipulative."

We are not persuaded that identifying deceptive or manipulative uses of visual media in advertising is so intrinsically burdensome that the State is entitled to forgo that task in favor of the more convenient but far more restrictive alternative of a blanket ban on the use of illustrations. The experience of the FTC is, again, instructive. Although that agency has not found the elimination of deceptive uses of visual media in advertising to be a simple task, neither has it found the task an impossible one: in many instances, the agency has succeeded in identifying and suppressing visually deceptive advertising.

Zauderer v. Office of Disciplinary Counsel, 471 U.S. 626, 649 (1985). 


\section{Compelled Disclosures of "Controversial Information"}

$A M I$ also holds that the Zauderer test should be applied only to mandated disclosures of "purely factual and uncontroversial information." shall close this brief discussion by considering why the D.C. Circuit might require information to be "uncontroversial." Plainly a mandated disclosure cannot become controversial merely because a speaker objects to making it. "[I]n the context of litigation controversy must mean more than the fact that some people may be highly agitated and be willing to go to court over the matter." 189 AMI itself characterizes the country-of-origin labels as uncontroversial even though the American Meat Institute objected vociferously to being forced to deploy them. Nor should mandated factual disclosures become constitutionally disfavored because they occur in circumstances of acrimonious political controversy. The need for sober factual disclosures might be most urgent in the context of socially contested issues like tobacco or obesity.

The requirement that information be "uncontroversial" would therefore seem best interpreted as a description of the epistemological status of the information that a speaker may be required to communicate. We should understand $A M I$ to hold that if the truth of information is seriously controverted, the state cannot appeal to the relaxed Zauderer test to sanction its compelled disclosure. This may be because compelled disclosure in such circumstances amounts to forcing a speaker to endorse one or another opinion about the truth of the underlying information. ${ }^{190}$

\section{CONCLUSION}

It is not unusual for judges in compelled commercial speech cases to begin their analysis with some variant of this thought:

Both the right to speak and the right to refrain from speaking are "complementary components of the broader concept of individual freedom of mind" protected by the First Amendment. Any attempt by the government either to compel individuals to express certain views, or to subsidize speech to which they object, is subject to strict scrutiny. The general rule "that the speaker has the right to tailor the speech[ ] applies not

\footnotetext{
188 Am. Meat Inst. v. U.S. Dep't of Agric., 760 F.3d 18, 21 (D.C. Cir. 2014) (emphasis added).

189 United States v. Philip Morris USA, Inc., 907 F. Supp. 2d 1, 18 (D.D.C. 2012).

190 Cf. CTIA v. San Francisco, 827 F. Supp. 2d 1054, 1060 (N.D. Cal. 2011), aff d per curiam, 494 F. App'x 752 (9th Cir. 2012) ("Whether or not cell phones cause cancer is a debatable question and, at this point in history, is a matter of opinion, not fact. San Francisco has its opinion. The industry has the opposite opinion. Can San Francisco force the industry to disseminate the government opinion?').
} 
only to expressions of value, opinion, or endorsement, but equally to statements of fact the speaker would rather avoid." This holds true whether individuals, see W. Va. State Bd. of Educ. $v$. Barnette, or corporations are being compelled to speak. $^{191}$

The deferential review of Zauderer is typically characterized as an exception to this broad and fundamental principle of speaker autonomy, ${ }^{192}$ an exception that must be narrowly construed because of the significance of the principle. The thought is that compelled speech, regardless of its circumstances, merits elevated First Amendment review. ${ }^{193}$

191 R.J. Reynolds Tobacco Co. v. FDA, 696 F.3d 1205, 1211 (D.C. Cir. 2012) (alteration in original) (citation omitted); see also Am. Meat Inst., 760 F.3d at 30 (Kavanaugh, J., concurring) ("As a starting point, all agree that the First Amendment imposes stringent limits on the Government's authority to either restrict or compel speech by private citizens and organizations."); Nat'l Ass'n of Mfrs. v. NLRB, 717 F.3d 947, 956-57 (D.C. Cir. 2013); United States v. Phillip Morris USA, Inc., 566 F.3d 1095, 1142 (D.C. Cir. 2009) ("The First Amendment protects against government infringement on the right to speak freely and the right to refrain from speaking at all. This holds true whether applied to individuals or to companies."); Cochran v. Veneman, 359 F.3d 263, 275-76 (3d Cir. 2004), judgment vacated on other grounds sub nom. Lovell v. Cochran, 544 U.S. 1058 (2005) (beginning its analysis by noting that "[t]he First Amendment protects the right to refrain from speaking and the right to refrain from association," and then applying this backdrop principle to a compelled commercial speech case); Int'l Dairy Foods Ass'n v. Amestoy, 92 F.3d 67, 71 (2d Cir. 1996) ("The right not to speak inheres in political and commercial speech alike."); Beeman v. Anthem Prescription Mgmt., LLC, 315 P.3d 71, 79 (Cal. 2013) (noting that the California constitution "does not exclude commercial speech from its protection" and that "freedom of speech under [California Constitution] article I includes both the right to speak and the right to refrain from speaking"); Gerawan Farming, Inc. v. Lyons 12 P.3d 720, 732 (Cal. 2000) ("The First Amendment's right to freedom of speech also protects commercial speech. ... The right in question comprises both a right to speak freely and also a right to refrain from doing so at all."); BellSouth Adver. \& Publ'g Corp. v. Tenn. Regulatory Auth., 79 S.W.3d 506, 516 (Tenn. 2002) (opening its First Amendment analysis in a commercial speech case by observing that the Amendment "not only bars the government from prohibiting protected speech, it also may bar the government from compelling the expression of certain views or the subsidization of speech to which an individual objects").

192 See R.J. Reynolds, 696 F.3d. at 1212.

193 In my view, this premise is almost certainly incorrect. See Robert Post, Compelled Subsidization of Speech: Johanns v. Livestock Marketing Association, 2005 SUP. CT. REV. 195. Yet I would be remiss if I did not allude to the ways in which this thought has been encouraged by loose rhetoric in United States v. United Foods. See, e.g., 533 U.S. 405, 410 (2001) ("Just as the First Amendment may prevent the government from prohibiting speech; the Amendment may prevent the government from compelling individuals to express certain views.... The fact that the speech is in aid of a commercial purpose does not deprive respondent of all First Amendment protection, as held in the cases already cited."). Also relevant are passages in the newer and more carelessly written opinion of Sorrell v. IMS Health, Inc., 131 S. Ct. 2653 (2011). Sorrell affirms that " $[t]$ he First Amendment requires heightened scrutiny whenever the government creates a regulation of speech because of disagreement with the message it conveys. . . Commercial speech is no exception." Id. at 2664. Although technically remaining within the doctrinal structure I have sketched in text, both United Foods and Sorrell seem to invoke a vague vision of 
We might pause for a moment and think about how this thought squares with the most rudimentary facts of commercial life. Consider ordinary real estate transactions, in which complex disclosures are routinely required. To be concrete, I am reproducing in the margin the disclosure requirements of the Consumer Leasing Act ("CLA"), a federal statute regulating all personal leases that exceed four months. ${ }^{194}$ It requires lessors to disgorge large quantities of information.

the autonomy of commercial speakers. Neither case, however, begins to address how the autonomy of commercial speakers might be reconciled with the web of regulation that applies to commercial actors. Neither case explains how the autonomy of commercial speakers might be rendered consistent with pervasive and accepted restrictions on deceptive and misleading commercial speech. Neither case explains how the autonomy of commercial speakers might be rendered consistent with the pervasive and accepted mandatory disclosures that blanket the commercial marketplace. Neither case has an account of what it might mean for commercial speakers to be "a little bit autonomous." See, e.g., Tamara R. Piety, "A Necessary Cost of Freedom"? The Incoherence of Sorrell v. IMS, 64 ALA. L. REV. 1 (2012).

194 The Consumer Leasing Act, 15 U.S.C. $\$ 1667 \mathrm{a}$, requires that

Each lessor shall give a lessee prior to the consummation of the lease a dated written statement on which the lessor and lessee are identified setting out accurately and in a clear and conspicuous manner the following information with respect to that lease, as applicable:

(1) A brief description or identification of the leased property;

(2) The amount of any payment by the lessee required at the inception of the lease;

(3) The amount paid or payable by the lessee for official fees, registration, certificate of title, or license fees or taxes;

(4) The amount of other charges payable by the lessee not included in the periodic payments, a description of the charges and that the lessee shall be liable for the differential, if any, between the anticipated fair market value of the leased property and its appraised actual value at the termination of the lease, if the lessee has such liability;

(5) A statement of the amount or method of determining the amount of any liabilities the lease imposes upon the lessee at the end of the term and whether or not the lessee has the option to purchase the leased property and at what price and time;

(6) A statement identifying all express warranties and guarantees made by the manufacturer or lessor with respect to the leased property, and identifying the party responsible for maintaining or servicing the leased property together with a description of the responsibility;

(7) A brief description of insurance provided or paid for by the lessor or required of the lessee, including the types and amounts of the coverages and costs;

(8) A description of any security interest held or to be retained by the lessor in connection with the lease and a clear identification of the property to which the security interest relates; 
State statutes typically demand even more disclosure than the CLA. Legislation in the state of Washington requires that sellers fill out a disclosure form indicating (among dozens of other things) whether there is an outdoor sprinkler system, whether the roof has leaked in the last five years, and whether there are any known defects to the property's hot tub or sauna. ${ }^{195}$ Statutes like these do not compel disclosure merely to prevent consumer deception. A lessor who fails to disclose particular information under the CLA is not ipso facto liable for common law negligent misrepresentation. ${ }^{196}$ Instead the purpose of such statutes seems to be to reduce information costs in the real estate market so as to improve transparency, efficiency, and fairness. ${ }^{197}$

This is compelled commercial speech in its rawest, most obvious form. Yet most literate members of the American legal profession would be surprised, if not shocked, at the thought that compelled disclosures in the context of real estate transactions pose any constitutional issue at all. In one form or another, such disclosures are accepted and routine. I have not been able to find even a single case using the First Amendment to challenge the CLA in which its disclosure requirements have been reviewed under the Zauderer test, much less under stricter forms of constitutional scrutiny.

It comes as something of a jolt to put these ordinary disclosure statutes against the high-minded constitutional principles of a decision like Barnette, which celebrates the autonomy of speakers from compelled avowals of government orthodoxy. It requires a tin ear to confuse required participation in a flag salute with the compelled disclosure of the "amount of other charges payable by [a] lessee not included in... periodic payments." 198 Both disclosures occur through the medium of speech, but speech is serving entirely

(9) The number, amount, and due dates or periods of payments under the lease and the total amount of such periodic payments;

(10) Where the lease provides that the lessee shall be liable for the anticipated fair market value of the property on expiration of the lease, the fair market value of the property at the inception of the lease, the aggregate cost of the lease on expiration, and the differential between them; and

(11) A statement of the conditions under which the lessee or lessor may terminate the lease prior to the end of the term and the amount or method of determining any penalty or other charge for delinquency, default, late payments, or early termination.

15 U.S.C. $\S 1667$ a (2013).

195 WASH. REV. CODE ANN. $§ 64.06 .013$ (West 2014).

196 For civil liability under the CLA, see 15 U.S.C. $\$ 1640$.

197 For example, the Senate Report on the CLA made clear that the legislation was motivated in part because "[ $[\mathrm{t}] \mathrm{he}$ bulk of current leases, either have no purchase option or involve much more than a nominal extra cost, and so do not contain all the information a consumer needs to make an intelligent comparison between leases, or between the lease and a credit purchase." $S$. REP. No. 94-590, at 3 (1976), reprinted in 1976 U.S.C.C.A.N. $431,433$.

198 CLA, supra note 194, § 1667a(4). 
different constitutional functions in each case. To conflate these distinct functions - to imagine that the same elevated First Amendment review is required simply because "speech as such"199 is involved-is to court intellectual incoherence and therefore doctrinal disaster.

To participate in public discourse, to take part in the formation of public opinion, is to exercise the sovereignty that democracy accords all members of "We the People." Sovereigns enjoy the privilege of determining their own future. The exercise of this privilege requires legal autonomy. Our First Amendment jurisprudence accordingly awards such autonomy to those who participate in public discourse. But, as Alexander Meiklejohn noted long ago, in a democracy "the governors and the governed are not two distinct groups of persons. There is only one group-the self-governing people. Rulers and ruled are the same individuals. We, the People, are our own masters, our own subjects. "200 If a democratic state deems the rental market in need of regulation, we produce anarchy rather than self-government if we do not accept our ability to rule ourselves.

When we participate in the commercial marketplace, therefore, we do not do so as sovereigns, but collectively as "our own subjects." It is not plausible to argue that we retain the prerogatives of sovereignty insofar as we are speaking. Virtually all human action in the commercial marketplace occurs through the medium of communication. Every real estate lease is a contract that exists in language; every rent control law limits the words we may express in a contract. The autonomy of commercial speakers is therefore inseparable from the "freedom of contract" upheld in Lochner. If we were autonomous whenever communicating in the market, we could never govern ourselves at all. ${ }^{201}$

Contemporary courts that affirm that all compelled commercial speech is a compromise of basic speaker autonomy fail to distinguish between the speech of citizens who rule themselves (public discourse) and the speech of citizens who are ruled (commercial speech). The former requires constitutional protections that do not apply to the latter. First Amendment jurisprudence recognizes this difference by constituting commercial speech as a distinct constitutional domain. Zauderer and Central Hudson both understood this clearly, and they fashioned doctrine appropriate for this end. They crafted doctrine focused on the need to safeguard an "informational function" rather than speaker autonomy.

The recent spate of compelled commercial speech cases requires us more fully to specify the constitutional stakes of compelling commercial

\footnotetext{
199 Glickman v. Wileman Bros. \& Elliott, Inc., 521 U.S. 457, 478 (1997) (Souter, J., dissenting).

200 Alexander Meiklejohn, Political Freedom: The Constitutional Powers of the PEOPLE 12 (1948).

201 See Robert Post, Recuperating First Amendment Doctrine, 47 STAN. L. REV. 1249, 125060 (1995).
} 
speakers to disclose information. Commercial speech merits constitutional protection because it communicates "information of import to significant issues of the day.... [C]ommercial speech serves to inform the public of the availability, nature, and prices of products and services." ${ }^{, 202}$ If the constitutional value of commercial speech lies in the circulation of information that is deemed relevant to the formation of public opinion, government compelled commercial speech must be deemed equally important to the formation of public opinion. This connection between compelled commercial speech and public discourse may underlie the doctrinal turbulence presently enveloping compelled commercial speech doctrine. It may, for example, go far to explain why the state cannot compel commercial disclosures of ideas or opinions. ${ }^{203}$

Compelled commercial speech may affect the substance of public opinion in at least two distinct ways. First, it may provide information pertinent for informed public decision-making. If the public is deliberating whether to regulate the real estate rental market, it is useful to know the prices and terms of available leases. This effect on public discourse is constitutionally desirable, for it is the justification advanced by the Court to explain why constitutional protections should extend to commercial speech. Democratic competence is a positive constitutional value.

Second, compelled commercial speech may affect how persons experience the salience and framing of information. If government compels the disclosure of prices and terms, as it does in the CLA or the TLA, ${ }^{204}$ it signals to the public that it ought to pay attention to these aspects of a commercial transaction. The implicit message is that members of the public should behave as rational economic actors. The disclosures required by the NLEA ${ }^{205}$ produce analogous framing effects. By emphasizing nutritional information like caloric content, they implicitly signal that members of the public ought to pay attention to their health when purchasing food. Insofar as the goal of the Act is to promote healthier food choices, the effectiveness of the Act trades on this salience effect. The disclosures required by the Dodd-Frank Wall Street Reform and Consumer Protection Act also produce framing effects. By making information about the use of conflict minerals available to interested members of the public, the Act signals that human rights violations in the Congo are relevant to public opinion.

The framing effects of the CLA or the NLEA seem primarily focused on transactions. They affect how we understand our own preferences as we purchase particular products. The framing effects of the Dodd-Frank Act, by contrast, seem to be more general. The conflict minerals reports required by

Bates v. State Bar of Ariz., 433 U.S. 350, 364 (1977).

203 See supra text accompanying notes 159-62.

204 See, e.g., 15 U.S.C. $\$ 1601$ (a) (2013).

205 Nutrition Labeling and Education Act of 1990, Pub. L. No. 101-535, 104 Stat. 2353. 
Dodd-Frank are not disclosed at the point of purchase for a product. They are instead made available on the internet for those who have the interest to read them. The framing effects of these reports may affect preferences relevant to purchasing products that contain conflict minerals, but they also seem designed to influence our views on human rights violations in the Congo. ${ }^{206}$

This difference may underlie the constitutional suspicion that the mandated Dodd-Frank disclosures have apparently aroused. The conflict mineral reports mandated by the SEC may be perceived as an effort to arouse public support for particular foreign policy objectives. Because democratic government must be responsive to public opinion, government efforts affirmatively to shape the content of public opinion can cause constitutional disquiet. $^{207}$

This disquiet requires close analysis. Government shapes the content of public opinion whenever it speaks, and government speech is ubiquitous. Decades ago there was concern that government might use its own speech to "dominate[] the minds of individuals, suppressing their ability to think critically about government leaders and policies." ${ }^{, 208}$ But recently there has been increasing acknowledgment that,

Democratic governments must speak, for democracy is a twoway affair. This is particularly true in representative democracies, where governments' speech must consist not just of information but also of explanation, persuasion, and justification to a polity tethered to the policies and preferences acted upon by its representatives.

The imperative of government speaking, and the roles occupied by government when it speaks, are vastly multiplied in the modern state. In domestic affairs, modern government is not limited to prohibitions. It is instead also a creator of rights and programs, a manager of economic and social relationships, a vast employer and purchaser, an educator, investor, curator, librarian, historian, patron, and on and on. Government inculcates values, defines justice, fairness, and liberty, and shapes behavior. It assures safety, protects the helpless and uninformed, and prevents injustice. It also places behavioral demands on its largess: it taxes and spends, subsidizes and

\footnotetext{
206 They also seem designed to affect investment decisions, rather than consumer decisions. Socially responsible investing is a growing phenomenon, involving assets counting in the trillions of dollars. See, e.g., Principles for Responsible Investment Fact Sheet, PRI, http://www.unpri.org/news/pri-fact-sheet/ (last visited Apr. 2, 2015).

207 See Alyssa Graham, The Government Speech Doctrine and Its Effect on the Democratic Process, 44 SUFFolK U. L. REV. 703 (2011).

208 Mark G. Yudof, When Government Speaks: Politics, Law, and Government EXPRESSION IN AMERICA 159 (1983).
} 
penalizes, encourages and discourages. None of these undertakings, and none of the roles the undertakings require government to assume, could be successfully pursued without speech by government. Government must explain, persuade, coerce, deplore, congratulate, implore, teach, inspire, and defend with words.

Government speech, then, must be understood as essential in a republican democracy, and as a necessary inference from the constitutional structure of American government. Speech is but one means that government must have at its disposal to conduct its affairs and to accomplish its ends. ${ }^{209}$

The Supreme Court has signaled its acceptance of the necessity and ubiquity of government speech by fashioning a robust First Amendment doctrine of "government speech." The Court has held that government must be free "to regulate the content" of its own speech and must be "entitled to say what it wishes." ${ }^{210}$ The Court has announced that constraints on government speech should lie primarily in the political process. "When the government speaks, for instance to promote its own policies or to advance a particular idea, it is, in the end, accountable to the electorate and the political process for its advocacy.",211

The Court's conclusions correspond to actual practice. No one would think twice if the public health department of a state were to issue a report seeking to raise public awareness about the dangers of obesity. Nor would any constitutional doubts arise if the United States Senate Committee on Foreign Relations were to publish a paper seeking to raise public awareness about human rights abuses in the Congo. We would regard such government speech as desirable and constructive.

The impact of compelled commercial speech on public discourse is analogous to that of government speech: both are methods of educating the public. By requiring the circulation of purely factual, uncontroversial information, the Dodd-Frank Act informs the public in a manner that is constitutionally comparable to reports by the Department of State or Senate Committee on Foreign Relations.

209 Randall P. Bezanson \& William G. Buss, The Many Faces of Government Speech, 86 IOWA L. REV. 1377, 1380 (2001).

210 Rosenberger v. Rectors \& Visitors of Univ. of Va., 515 U.S. 819, 833 (1995).

211 Bd. of Regents v. Southworth, 529 U.S. 217, 235 (2000); see Pleasant Grove City v. Summum, 555 U.S. 460, 467-68 (2009) ("The Free Speech Clause restricts government regulation of private speech; it does not regulate government speech. A government entity has the right to 'speak for itself.' '[I]t is entitled to say what it wishes,' and to select the views that it wants to express. Indeed, it is not easy to imagine how government could function if it lacked this freedom."). 
Of course, when government speaks in its own voice, we are alert to the possibility that it may be attempting to manipulate public opinion. We have learned to be wary of the political agendas that may lie behind many "official" government reports. ${ }^{212}$ We know that government is entering public discourse and attempting to shape it in accordance with its own views and opinions. If government were permitted to conscript the expression of ideas, compelled commercial speech might run the risk of corrupting public opinion with views manufactured by government requirements. But because compelled commercial speech is limited to the expression of purely factual information, its primary effect will be to increase democratic competence, which is an unqualified constitutional good. The question is whether the implicit framing effects of such speech might justify elevated constitutional concern.

In my view, these framing effects should not cause us any more constitutional concern than they do in the context of government speech itself. This is because most members of the public recognize government mandated labels and reports when they see them. We understand well enough that government is promoting the salience of certain facts rather than others. The origin of the required disclosures is apparent on the face of relevant statutes, and we are therefore empowered "to take accountability measures as appropriate." 213 Compelled commercial speech does not pose a problem of stealth or ventriloquism. It does not "create the misleading impression that the relevant realm of public debate is unaffected by government participation."214

The close analogy between government speech and compelled commercial speech does suggest, however, that if the state is prohibited from using its own speech to pursue a particular purpose, it should also be prohibited from accomplishing the same end through the medium of compelled commercial speech. There is great suspicion of government speaking in ways that directly intervene "to promote a partisan position in an election campaign," especially if the purpose of government speech is "'promotional,' rather than "informational.",215 Although recent cases have been somewhat more tolerant

\footnotetext{
212 Lawrence Lessig calls this the "Orwell effect." Lawrence Lessig, The Regulation of Social Meaning, 62 U. CHI. L. REv. 943, 1017-18 (1995) ("[W] hen people see that the government or some relatively powerful group is attempting to manipulate social meaning, they react strongly to resist any such manipulation. What the Orwell effect means is that efforts by the government to regulate social meaning that are seen as efforts by the government to change social meaning will be less effective than efforts that are not so viewed.").

213 Helen Norton, The Measure of Government Speech: Identifying Expression's Source, 88 B.U. L. REv. 587, 597 (2008).

214 Gia B. Lee, Persuasion, Transparency, and Government Speech, 56 HastingS L.J. 983, 1013 (2005).

215 Stanson v. Mott, 551 P.2d 1, 1 (Cal. 1976); cf. Citizens to Protect Pub. Funds v. Bd. of Educ., 98 A.2d 673 (N.J. 1953); Burt v. Blumenauer, 699 P.2d 168 (Or. 1985); Cass R. Sunstern, Democracy and the Problem of Free SPeECh 231 (1993); Steven Shiffrin,
} 
of promotional government speech in the context of initiatives and pending state legislation, ${ }^{216}$ we may infer from this suspicion that it would be constitutionally questionable for government to interfere in partisan elections by requiring products to carry labels disclosing the political party affiliation of members of a manufacturer's board of directors.

It is entirely appropriate to reason in this way from the constitutional analogy between government speech and compelled commercial speech. Pursuing this analogy allows us better to understand some of the constitutional parameters of compelled commercial speech. It does so without appealing to the autonomy of commercial speakers. That recent cases repeatedly return to the theme of the autonomous commercial speaker is disturbing. It suggests that judicial hostility to compelled commercial speech may not reflect actual First Amendment concerns, but instead a fundamental suspicion of the modern administrative state and its regulation of commercial actors. ${ }^{217}$ How else are we to interpret the recent and provocative references to Lochner in the midst of what purports to be a discussion of First Amendment jurisprudence? $?^{218}$

Conscripting the First Amendment to an anti-regulatory agenda would be a grave constitutional abuse. Freedom of speech allows us to discuss and decide whether we wish to adopt the values of libertarianism; it does not itself impose libertarian values on commercial regulation. As Ed Baker knew well, there is an unresolvable tension between aspiring to protect the autonomy of commercial speakers, which seems to be influencing so many recent compelled commercial speech opinions, and the pervasive regulation of commercial actors exemplified by humdrum legislation like the CLA. So long as we remain caught in the torque of this tension, we can expect only deepening doctrinal obscurity.

Government Speech and the Falsification of Consent, 96 HARV. L. REv. 1745, 1750-51 (1983); Steven Shiffrin, Government Speech, 27 UCLA L. REV. 565, 612-17, 622-32 (1980).

216 See, e.g., Page v. Lexington Cnty. Sch. Dist. One, 531 F.3d 275 (4th Cir. 2008); Kidwell v. City of Union, 462 F.3d 620 (6th Cir. 2006).

217 See supra text accompanying notes 3-5.

218 See supra text accompanying note 5. 
